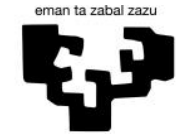

Universidad del País Vasco
Euskal Herriko Unibertsitatea

\title{
Manganeso dioxidozko superkondentsadore hibridoen karakterizazio elektrokimikoa
}

Egilea:

Jon Rodriguez Romero Zuzendariak:

Idoia Ruiz de Larramendi Villanueva Eider Goikolea Nuñez 

Gradu Amaierako Lana

Kimikako Gradua

\section{Manganeso dioxidozko superkondentsadore hibridoen karakterizazio elektrokimikoa}

Jon Rodriguez Romero-k aurkeztutako memoria

Matrikulazioa: Uztaila eta iraila 2019

Zuzendariak: Idoia Ruiz de Larramendi Villanueva eta Eider Goikolea Nuñez

Saila: Kimika Ez-organikoa 



\section{LABURDURAK ETA AKRONIMOAK}

\begin{tabular}{|c|c|}
\hline$\Delta \mathrm{E}$ & Potentzial aldakuntza \\
\hline $\mathrm{AC}$ & Ikatz aktibatua \\
\hline BET & Brunauer-Emmett-Teller \\
\hline $\mathrm{C}$ & Kapazitantzia \\
\hline$C^{\prime}$ & Kapazitantzia espezifikoa \\
\hline $\mathrm{CNO}$ & Ikatzezko nano-tipulak \\
\hline $\mathrm{CV}$ & Voltamperometria ziklikoak \\
\hline $\mathrm{EC}$ & Kondentsadore elektrokimikoa \\
\hline EDL & Geruza bikoitz elektrikoa \\
\hline EDLC & Geruza bikoitz elektrikozko kondentsadorea \\
\hline FWHM & Altuera erdiko zabalera \\
\hline JCPDS & Joint Committee on Powder Diffraction Standards \\
\hline GA & Karga/deskarga galvanostatikoak \\
\hline I & Korronte dentsitatea \\
\hline ICP-AES & $\begin{array}{l}\text { Plasmaz induzitutako igorpen atomikoko } \\
\text { espektroskopia }\end{array}$ \\
\hline IUPAC & Kimika Puru eta Aplikatuko Nazioarteko Batasuna \\
\hline $\mathrm{KOH}$ & $1 \mathrm{M} \mathrm{KOH}$ elektrolitoa \\
\hline $\mathrm{m}$ & Masa \\
\hline $\mathrm{MnO}_{2} 600$ & $600{ }^{\circ} \mathrm{C}$-ra tratatutako $\mathrm{MnO}_{2}$ lagina \\
\hline $\mathrm{Na}_{2} \mathrm{SO}_{4}$ & 0,5 $\mathrm{M} \mathrm{Na}_{2} \mathrm{SO}_{4}$ elektrolitoa \\
\hline $\mathrm{NaMn}$ & $0,5 \mathrm{M} \mathrm{Na}_{2} \mathrm{SO}_{4}+0,2 \mathrm{mM} \mathrm{MnSO}_{4}$ elektrolitoa \\
\hline NEt4BF4 & Tetraetilamonio tetrafluoroborato \\
\hline Q & Karga \\
\hline RTIL & Inguru tenperaturako likido ionikoak \\
\hline SEM & Ekortze mikroskopia elektronikoa \\
\hline SSA & Azalera espezifikoa \\
\hline TEM & Transmisioko mikroskopia elektronikoa \\
\hline TG & Analisi termograbimetrikoa \\
\hline PTFE & Politetrafluoroetileno \\
\hline $\mathrm{V}$ & Sistemaren tentsioa \\
\hline XRD & $\mathrm{X}$ izpien difrakzioa \\
\hline
\end{tabular}





\section{AURKIBIDEA}

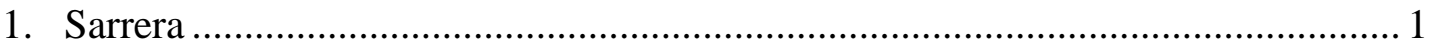

1.2. Bateriak vs Superkondentsadoreak............................................................. 1

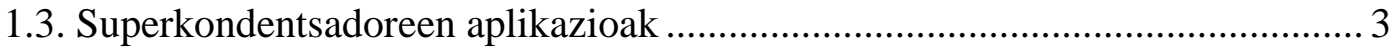

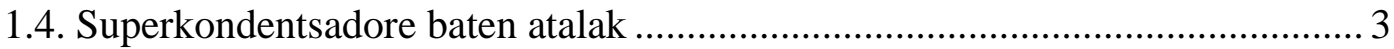

1.5. Superkondentsadore eta elektrodo motak..................................................... 4

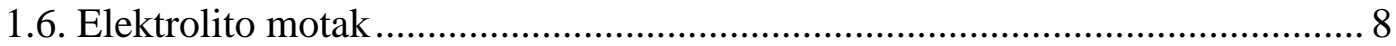

1.7. Trantsizio metal oxidoak elektrodo pseudokapazitibo modura........................9

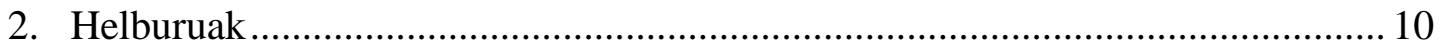

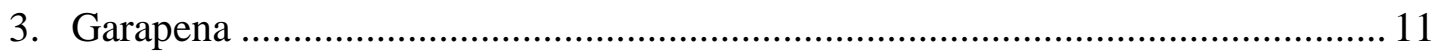

3.1. $\mathrm{MnO}_{2}$-aren sintesia eta karakterizazio fisiko-kimikoa .................................. 11

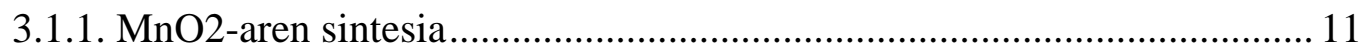

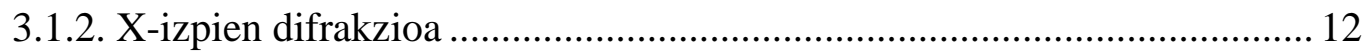

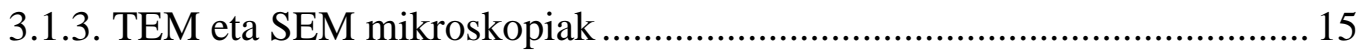

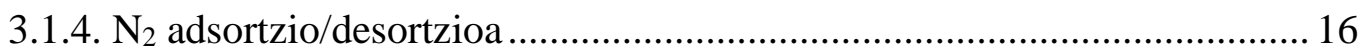

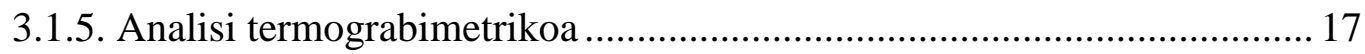

3.2 $\mathrm{MnO}_{2}$-en eta $\mathrm{AC}$-aren karakterizazio elektrokimikoa ..................................... 19

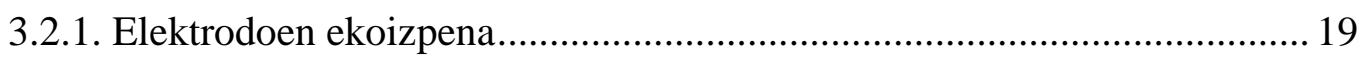

3.2.2. Elektrodoen karakterizazio elektrokimikoa ........................................... 20

3.3. Sistema finalaren karakterizazio elektrokimikoa ........................................... 25

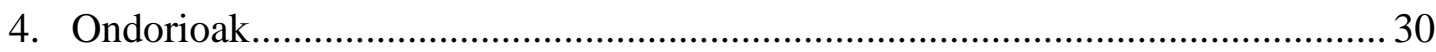

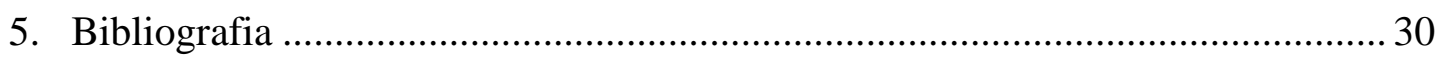





\section{SARRERA}

Klima aldaketak, egungo eredu energetikoak, erregai fosilen eskasiak eta gainpopulazioak gizartea energia iturri berriztagarri eta iraunkorren bilaketara bultzatzen dute. Honen ondorioz, azken hamarkadetan bulkada handia eman zaie energia eoliko, hidrauliko, eguzki-energia eta beste energia ekoizpen modu alternatiboei. Baina energia iturri hauetako asko aldizkakoak eta ausazkoak dira, hau da, klima, eguraldi edota egun/gauaren menpe daudenez eta gehienetan energiaeskaera handiena duten orduak eta produkzio-orduak bat ez datozenez, energia biltegiratzeko sistemak beharrezkoak dira. Helburu hau betetzeko diseinatutako sistemen artean, bateriak eta superkondentsadoreak (ingelesez electrochemical capacitors, EC) azpimarra daitezke, nahiz eta gure etorkizuneko premiak hornitzeko aurrerapen handiak egin behar diren oraindik. Bereziki, gaur egun gailu elektroniko mugikorrak, ibilgailu elektrikoak (hibridoak edo erabat elektrikoak) eta ekipamendu industrial handiak optimizatzeko premia dago, eta horretarako material eta sistema berriak garatu eta interfase elektrokimikoak sakonago ikertu behar dira nano-eskalan.

\subsection{BATERIAK VS SUPERKONDENTSADOREAK}

Li-ioi bateriak 1990. urtean aurkeztu zituen Sony-k, Whittingham, Scrosati eta Armand-en lan aitzindaria jarraituz. ${ }^{1}$ Garestiak diren arren, bateria hauek eraginkorrenak dira, $180 \mathrm{Wh} / \mathrm{kg}$-ko energia dentsitateak lortuz. Nahiz eta ikerkuntza ugari egin diren Li-ioi bateriak hobetzeko edota nanomaterialez eta erredox bikote $\operatorname{organikoz}^{2-4}$ egindako sistemak sortzeko, bateria hauen karga-deskarga denbora luzeak direla eta, duela urte gutxi batzuk arte ez zaie superkondentsadoreei behar bezalako arreta eskaini. Izan ere, superkondentsadoreek ezin dute bateriek beste energia biltegiratu ( $10 \mathrm{Wh} / \mathrm{kg})$, baina potentzia askoz handiagoarekin deskargatu eta kargatu daitezke, beraz, segundo gutxi batzuetan bateria batek baino energia dentsitate handiagoa askatzeko gai dira $(\sim 10 \mathrm{~kW} / \mathrm{kg}) .{ }^{5}$ Energia biltegiratzeko zenbait sistemen energia eta potentziaren arteko erlazioa 1. Irudian erakusten den Ragone plot-ean ikus daiteke. $^{6}$ 


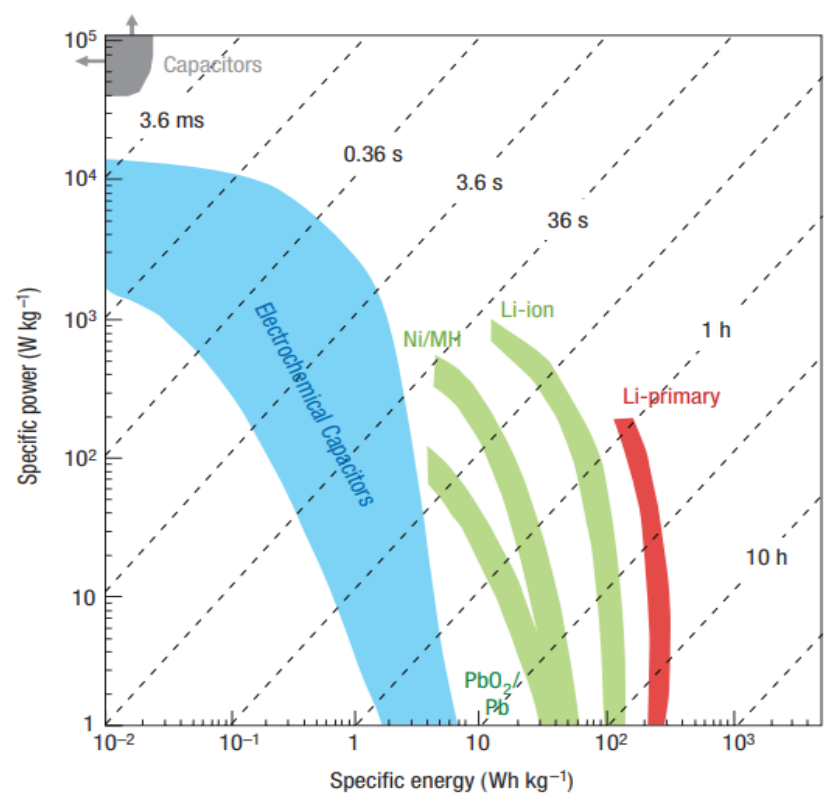

\section{Irudia: Energia biltegiratzeko gailuen errendimendua azaltzen duen grafikoa:} Ragone plot. ${ }^{6}$

Hala ere, energia eta potentziaz gain, beste hainbat ezaugarri erabakigarriak izango dira aplikazio jakin baterako sistema bat ala bestea aukeratzeko orduan. Aldagai horiek prezioa, tenperatura tarte eraginkorra, ziklabilitatea, segurtasuna eta ingurugiroarekiko adeitasuna dira. Merkatuan, superkondentsadore baten kostua $20.000 \$ / \mathrm{kWh}$ ingurukoa da, Li-ioi bateriena 1000 \$/kWh-koa den bitartean. ${ }^{7}$ Hala ere, superkondentsadore batek millioi bat karga/deskarga ziklo baino gehiago egin ditzake eta bere ahaideak berriz 1000-2000 ziklo. Datu hauen arabera superkondentsadoreen kostua zikloko 0,02 \$/kWh-koa da eta bateriena, aldiz, 1 \$/kWh-koa, beraz epe luzean bateriak garestiagoak direla esan daiteke. Beste ezaugarri kritiko bat segurtasuna da, bateria gehienek litioaren pareko ioi metalikok izan ohi dituzte beren baitan eta horrek erreakzio kimiko suntsikorrak eta exotermikoak sor ditzake, ondorioz, bateria eta honek elikatzen duen gailua matxuratuz. Superkondentsadoreetan ez dira horrelako materialak erabiltzen, horregatik, eta beraien tenperatura tarte eraginkor zabalagoagatik, superkondentsadoreek baldintza bortitzagoetan lan egin dezakete mantentze-lan erregularrik gabe. Dena den, nahiz eta sistema baten eta bestearen alde on eta txarrak konparatu diren, bateriak eta superkondentsadoreak ez dira lehiakideak bezala ikusi behar, izan ere, bi teknologia hauek osagarriak izaten dira sarritan. 
Azpimarratzekoa da ere, ikerkuntza eta merkatu mailan, superkondentsadoreek duten energia dentsitate maila kapazitantzia-ren bitartez (farad-etan, F, neurtua) neurtzen dela, baterietan kapazitate-az (miliampere orduko, mAh) hitz egiten den bitartean. Ohar bezala, aipatzekoa da bi magnitudeak $C$ hizkiarekin adierazi ohi direla, baina ikerkuntza lan honetan laburdura horren bitartez kapazitantzia adieraziko da.

\subsection{SUPERKONDENTSADOREEN APLIKAZIOAK}

Superkondentsadoreen energia biltegiratzeko eta askatzeko mekanismoa dela eta, beren energia bulkadak hastapen motorretan bereziki erabilgarriak dira. Gaur eguneko Estatu Batuetako superkondentsadore merkatuaren eskaeraren \% 70-a autobus eta tranbietara bideratua dago. Estatu mailan, sistema hauek CAF S.A. enpresak beraien Greentech teknologian darabil, tranbiak katenaria gabeko lekuetan elektrizitatez hornitzeko. ${ }^{8}$ Horretaz aparte, energia iturri berriztagarrietan (adibidez haize errota baten turbinaren abiadura doitzeko), hegazkinen larrialdi ateetan, zeinbait makina (orga jasotzaileak, garabiak) edota aparatu elektronikoetan (segurtasun-kopia sistemetan) erabiltzen dira. ${ }^{9,10}$ Zenbait superkondentsadore komertzialen parametroen helmena 1. Taulan bilduta daude.

1. Taula: Superkondentsadore komertzialen ezaugarri nagusiak

\begin{tabular}{rccccc}
\hline Etxe komertziala & $\begin{array}{c}\text { Tentsioa } \\
(\mathbf{V})\end{array}$ & $\begin{array}{c}\text { Kapazitantzia } \\
(\mathbf{F})\end{array}$ & $\begin{array}{c}\text { Energia } \\
(\mathbf{W h} / \mathbf{k g})\end{array}$ & $\begin{array}{c}\text { Potentzia } \\
(\mathbf{k W} / \mathbf{k g})\end{array}$ & $\begin{array}{c}\text { Masa } \\
(\mathbf{g})\end{array}$ \\
\hline Maxwell $^{11}$ & 2,70 & 3000 & 6,0 & 5,9 & 510 \\
Yunasko $^{12}$ & 2,70 & 3000 & 6,2 & 7,1 & 490 \\
NipponChemi-Con $^{13}$ & 2,50 & 1400 & 4,6 & - & 280 \\
Ioxus $^{14}$ & $2,70 / 2,85$ & 3000 & 6,2 & 10,1 & 510 \\
JM energy $^{15}$ & $3,80-2,20$ & 3300 & 13,0 & - & 350 \\
Wimaa $^{16}$ & 2,50 & 3000 & 4,7 & - & 615 \\
Skeleton $^{17}$ & 2,85 & 3200 & 6,8 & 42,0 & 533 \\
\hline
\end{tabular}

\subsection{SUPERKONDENTSADORE BATEN ATALAK}

Superkondentsadore batek hiru atal nagusi ditu: (i) bi elektrodo, bakoitza korronte bilgailu batekin kontaktuan, sistema osoa zirkuitu elektriko batera konektatzen 
dutenak; (ii) elektrodoen arteko bereizgailu bat, garraiatzaile ionikoa baina isolatzaile elektronikoa dena, eta (iii) elektrolitoa (2. Irudia).

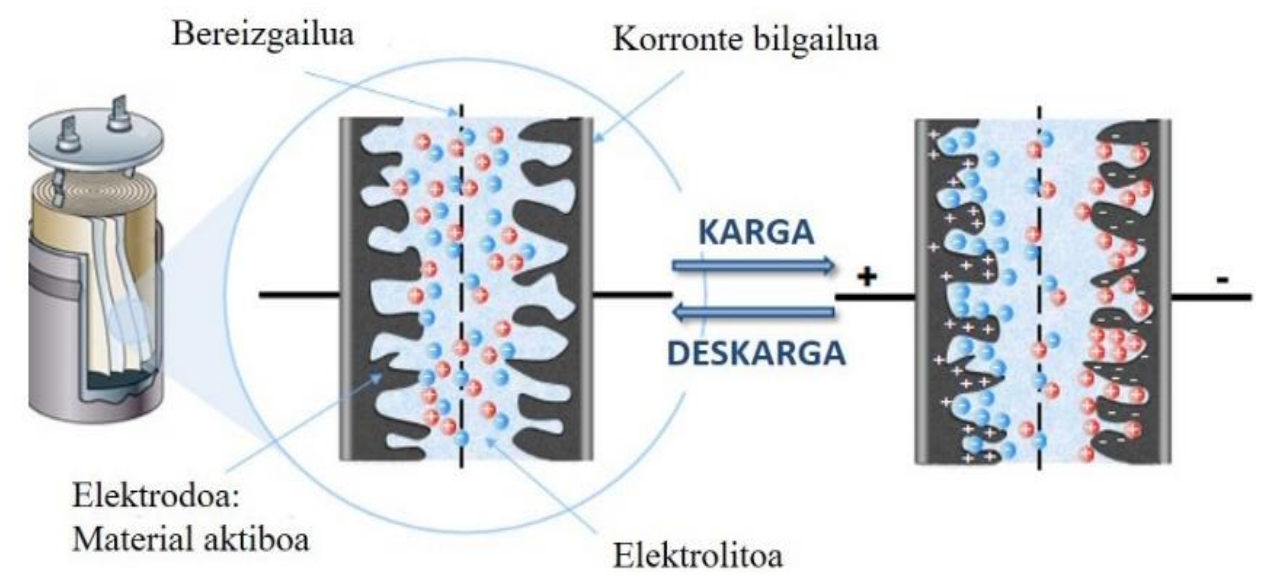

2. Irudia: Karga metaketa mekanismo elektrostatikoa. ${ }^{18}$

Bereizgailuak gelaxkaren tamaina minimizatzea ahalbidetzen du; zirkuitu laburra saihesten du bi elektrodoak ukitzea ekidituz eta elektrolitoan dauden ioien mugimendua ahalbidetzen du. Elektrikoki, elektrodo bakoitza banakako kondentsadore bat bezala adierazi daiteke, beraz bi elektrodoak seriean konektatutako kondentsadore bezala kontsideratu daitezke. ${ }^{19}$ Elektrodoak izendatzeko sistema kargatzean bakoitzaren potentzial aldakuntza $(\Delta E)$ hartzen da irizpide moduan, hots, potentzial balio txikiagoetara jotzen duen elektrodoari elektrodo negatibo deritzo eta potentzial igoera jasaten duenari berriz, elektrodo positibo. Baterietan ez bezala, non katodo eta anodo hitzak erabiltzen diren, superkondentsadoreen arloan nomenklatura hau da ohikoena,. Elektrodoen arteko potentzial diferentziak determinatuko du sistemaren tentsioa $(V)$. Hala ere, elektrolitoaren lan-tentsioa $\left(\Delta E_{\text {elektrolito }}\right)$ mugatua egon daiteke, potentzial balio batzuetatik gora edo behera deskonposatu egin daiteke eta; beraz, elektrolito aproposa aukeratzea garrantzitsua da superkondentsadore eraginkorra eraikitzeko orduan.

\subsection{SUPERKONDENTSADORE ETA ELEKTRODO MOTAK}

Superkondentsadore motak orokorrean elektrodoen izaeraren arabera sailkatzen dira. Elektrodo berdintsuak badira (material eta masa berdinekoak), sistema simetrikoa dela esaten da. Elektrodoak ezberdinak badira, aldiz, sistema asimetrikoa dela esan ohi da. Bestalde, energia biltegiratzeko mekanismoaren arabera, bi superkondentsadore mota 
bereiz daitezke. Alde batetik EDLC-ak (ingelesez electrical double layer capacitor, ez faradikoak) topa ditzakegu, zeinetan energia biltegiratzea elektrodo/elektrolito interfasean elektrostatikoki metatutako kargetan oinarritzen den. Bestetik, pseudokondentsadoreak daude (faradikoak), zeinetan karga eta deskarga, behintzat elektrodo bateko materialean gertatzen diren gainazaleko erredox erreakzio azkar eta itzulgarriei esker gertatzen den. Aipatzekoa da bi sistema ezberdin hauen erantzun elektrokimikoa berdina dela nahiz eta prozesuak desberdinak diren.

Sistema simetrikoak, EDLC-ak direnak, orokorrean, oso gainazal espezifiko (ingelesez specific surface area, SSA) altua duten materialez eginda daude, sistema hauen errendimendua zuzenki erlazionatuta baitago materialaren azalera espezifikoarekin. Izan ere, estimulu elektriko batek bultzatutako elektrodoaren gainazalean gertatzen den karga elektrostatikoen metaketan oinarritzen dira (ikusi 2. Irudia). Karga prozesuan, elektrodo negatiboaren gainazala elektrolitoan dauden ioi positiboz estaltzen da elektrosortzioz, eta neutralitatea mantentzeko, elektrodo positiboan ioi negatiboak metatzen dira; bi elektrodoetan geruza bikoitz elektrikoa (ingelesez electrical double layer, EDL) deritzona sortuz. Esan bezala, karga prozesu honek potentzialaren jaitsiera eragiten du elektrodo negatiboan eta igoera, aldiz, positiboan. Korrontea inbertitzean, hau da, deskarga prozesuan, ioiak berrantolatzen dira hasierako egoerara bueltatuz, eta horrekin batera energia askatuz. ${ }^{20}$ EDLC-en elektrodoetan erabilitako material ohikoenak ikatzak dira: grafenoa, ${ }^{21}$ ikatz tipulak (ingelesez carbon nano-onions, $\mathrm{CNO}$ ), ${ }^{22}$ eta aipagarrienak, ikatz aktibatuak (ingelesez activated carbons, AC-ak) (poro tamaina $<2 \mathrm{~nm}$ ); beraien prezio baxu, eskuragarritasun eta azalera espezifiko balio altuagatik $\left(>1000 \mathrm{~m}^{2} / \mathrm{g}\right){ }^{23}$

Sistema asimetrikoetan, badaude masa desberdina duten edota ikatz mota desberdinak erabiltzen dituzten sistemak, baina aurreko elektrosortzio-mekanismoari jarraituz funtzionatzen dutenak. Hala ere, ez da ohikoena, izan ere, gelaxka asimetrikoak EDLC-ek dituzten kapazitantzia maximoak gainditzeko helburuarekin sortuak baitira. ${ }^{24,25}$ Superkondentsadore batek biltegira dezakeen energia ( $\mathrm{Wh} \mathrm{kg}^{-1}$ edo $\mathrm{Wh} \mathrm{dm}^{-}$ ${ }^{3}$-tan neurtua), $E_{S C}$, sistemaren kapazitantziaren eta gelaxkaren tentsioaren araberakoa da (1. Ekuazioa), beraz energia altuagoak lortzeko bi parametro horiek hobetu behar dira. 


$$
E_{S C}=\frac{1}{2} C V^{2}
$$

Kapazitantzia hobetzeko, ikatzen ordez erredox erreakzioak jasaten dituzten materialak erabiltzen dira. Material hauen erabilerak prozesu elektrostatikoak eta faradikoak konbinatzen dituzten superkondentsadoreak edota prozesu faradiko desberdinak erabiltzen dituzten superkondentsadoreak eraikitzea ahalbidentzen ditu. Erreakzio kimikoen bidez, EDL-an lortzen diren $5 \mu \mathrm{F} / \mathrm{cm}^{2}$ inguruko kapazitantzia balioak baino bi magnitude orden gehiagoko balioak lor daitezke. ${ }^{26}$ Hala ere, material hauek, pseudokapazitibo bezala ezagutzen direnak, beste propietate batzuetan huts egin ohi dutenez (eroankortasun baxua, ziklabilitate txarra, potentzia dentsitate baxua...), askotan material konposatuak edo konpositeak prestatu behar dira emaitza onak lortzeko. Gainera, mekanismo hauetan gertatzen diren erredox erreakzioen zinetika ez da prozesu elektrostatikoen zinetikaren parekoa, eta hori potentzia balio altuetan islatzen da. Era berean, erredox erreakzioak itzulgarriak eta azkarrak izan arren, ez daude EDLC sistemen ziklabilitate maila berean; aitzitik, baterien parera daudela esan daiteke. Bateriak aipatuta, sistema asimetrikoetan sistema hibridoak ere bereiz ditzakegu, EDLC motako elektrodo bat bateria motako elektrodo batekin konbinatuz eraikitzen direnak bi teknologia ezberdinen abantailak aprobetxatzeko asmoz.

Beraz, prozesu faradikoak jasaten dituzten elektrodoak bi motatan sailka daitezke, pseudokapazitiboak eta bateria motako elektrodoak. Lehenengoen kapazitantzia, elektrodoen gainazalean gertatzen diren erredox erreakzio itzulgarrietatik dator, eta bigarrenetan erredox erreakzioak elektrodo guztian zehar gertatzen dira. ${ }^{26}$ Elektrodo pseudokapazitiboak trantsizio metal oxidoak (adibidez $\mathrm{RuO}_{2}, \mathrm{MnO}_{2}, \mathrm{CoO}_{\mathrm{x}}, \mathrm{NiO}$, $\mathrm{Fe}_{2} \mathrm{O}_{3}$, etab.) ${ }^{27}$ edo polimero eroaleak (polipirrola, polianilina edo poli(3,4-etilenedioxitiofenoa) besteak beste) ${ }^{27}$ izan ohi dira. Aipatu beharrekoa da baterietako eta EDLC-etako elektrodoak konbinatzen dituzten sistemetan, elektrodo negatiboaren papera lehenengoak bete ohi duela, ikatzezko elektrodoa positiboa den bitartean. Elektrodo pseudokapazitiboak eta EDLC elektrodoak erabiltzen dituzten sistemetan, berriz, materialen ezaugarriengatik kontrako konfigurazioa erabiltzen da 
gehienetan: elektrodo positiboa pseudokapazitiboa da eta negatiboa EDLC motakoa. Elektrodo eta konfigurazioen sailkapen laburtua 3. Irudian ikusi daiteke.

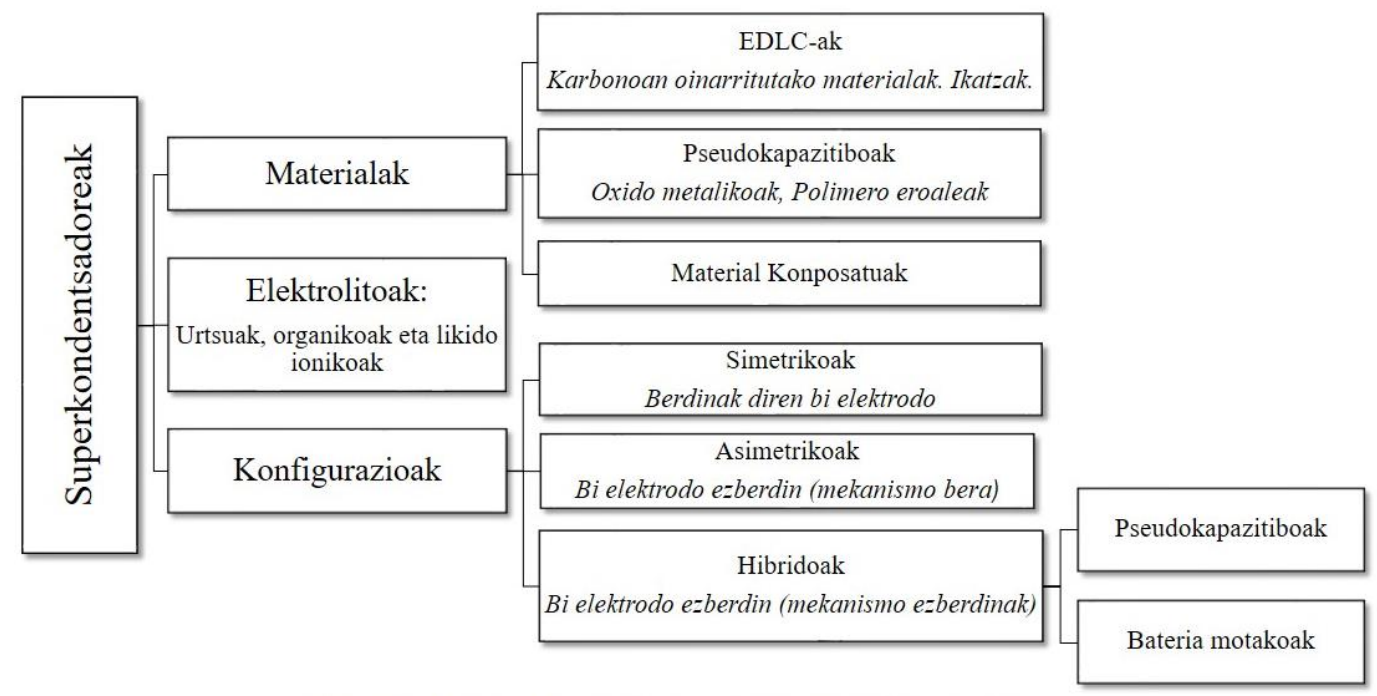

\section{Irudia: Superkondentsadoreen taxonomia diagrama eskematikoa. 19. erreferentziatik moldatua.}

Sistema asimetrikoetan, elektrodo bakoitzak izaera ezberdina duenez, banakako azterketa egitea beharrezkoa da bakoitzaren lan potentzial tartea, $\Delta E_{+}$edo $\Delta E_{\text {, }}$, zeintzuk diren jakiteko. Informazio horrekin sistema finalaren gutxi-gorabeherako lantentsioa, aurresatea espero da, lehenago aipatu den bezala, $\Delta E_{+}, \Delta E_{\text {- }}$ eta $\Delta E_{\text {elektrolito-ren }}$ menpe dagoena. Gainera, sistema optimizatzeko beharrezkoa da banakako elektrodoen kapazitantzia jakitea, masa balantze baten bidez karga negatibo eta positiboak berdintzeko. Berdinketa hau egiteko, kontuan izan behar da kapazitantzia, karga $(Q)$ eta potentzial diferentziaren $(\Delta E)$ zatiketa dela (2. Ekuazioa) eta normalean, superkondentsadoreetan, kapazitantzia espezifikoa, $C^{\prime}$, dela energia dentsitatea emateko erabiltzen den magnitudea (3. Ekuazioa).

$$
\begin{aligned}
& C=\frac{Q}{\Delta E} \\
& C^{\prime}=\frac{C}{m}
\end{aligned}
$$


Masa balantzea egiteko, elektrodo bakoitzak metatzen dituen kargak berdindu (4. Ekuazioa) eta horrela bi elektrodoen masek zein erlazio bete behar duten lor daiteke (5. Ekuazioa).

$$
\begin{gathered}
Q_{+}=m_{+} C_{+}^{\prime} \Delta E_{+}=m_{-} C_{-}^{\prime} \Delta E_{-}=Q_{-} \\
\frac{m_{+}}{m_{-}}=\frac{C_{+} \Delta E_{+}}{C_{-} \Delta E_{-}}
\end{gathered}
$$

\subsection{ELEKTROLITO MOTAK}

Jakina denez, superkondentsadoreen eraginkortasunerako giltza elektrodoetan dago; hala ere, elektrolito egokiaren aukeraketa faktore erabakigarria da emaitza onak lortzeko. Elektrolitoak disoluzioak izan ohi dira, disolbatzailearen arabera bereizten direnak: organikoak edo urtsuak. Elektrolito urtsu erabilienak $1 \mathrm{M} \mathrm{H}_{2} \mathrm{SO}_{4}$ eta $6 \mathrm{M} \mathrm{KOH}$ dira. Elektrolito hauek gutxi gorabehera $1 \mathrm{~V}$-ko potentzial diferentzian egonkorrak dira, uraren egonkortasun termodinamikoak baldintzatuta $(1,23 \mathrm{~V}$ baino potentzial handiagoan deskonposatzen da). Elektrolito organikoen artean azetonitriloan edo propilen karbonatoan disolbatutako $1 \mathrm{M}$ tetraetilamonio tetrafluoroboratoa $\left(\mathrm{NEt}_{4} \mathrm{BF}_{4}\right)$ da ohikoena. ${ }^{28}$ Disoluzio hauek gelaxkaren tentsioa $3 \mathrm{~V}$-ra arte zabal dezakete, eta are gehiago sistema asimetriko batean. Dena den, elektrolito urtsuek ez bezala, organikoek hainbat alde txar dituzte, besteak beste gelaxkaren muntaia atmosfera geldoan egin behar dela eta garestiak eta askoz kutsakorragoak direla. ${ }^{29}$ Hala ere, industrialki erabilienak organikoak dira, potentzial diferentzia handiagoa eskaintzen dutenez, energia dentsitate handiagoak lor ditzaketelako (Ikusi 1. Ekuazioa). Azken urteotan aukera berri bat frogatu da, RTIL edo inguru tenperaturako likido ionikoak hain zuzen ere (ingelesez room temperature ionic liquids). Hauekin $3 \mathrm{~V}$ baino gehiagoko potentzial leihoak lortu dira, baina kapazitantzia balioak ez dira behar bezain onak eroankortasun murriztua eta bateragarritasun txikia dutelako AC mikroporotsuekin ioien tamaina handiagatik. $^{30}$ Hala ere, erabilgarriak izan daitezke superkondentsadoreak muturreko tenperaturatan erabiltzeko. ${ }^{31} 2$. Taulan elektrolito mota bakoitzaren ezaugarriak laburbildu dira. 
2. Taula: Ohiko elektrolitoen propietateak. 19. Erreferentziatik moldatua.

\begin{tabular}{cccc}
\hline & Urtsuak & Organikoak & RTIL \\
\hline Potentzial leihoa (zel. sim.) & $0,7-1,0$ & $2,7-3,0$ & $3,0-$ \\
& & & 5,0 \\
Kapazitantzia maximoa (F/g) & $<300^{*}$ & $<200$ & $<120$ \\
Tenperatura tartea $\left({ }^{\circ} \mathbf{C}\right)$ & $\sim 1000^{\dagger}$ & & $0-$ \\
Eroakortasun elektrikoa $(\mathbf{m S} / \mathbf{c m})$ & $400-800^{\ddagger}$ & $10-60$ & $10-$ \\
& $\mathrm{T}_{\text {inguru }}$ & $-45-60$ & 20 \\
\hline
\end{tabular}

\subsection{TRANTSIZIO METAL OXIDOAK ELEKTRODO PSEUDOKAPAZITIBO MODURA}

Metal oxido/hidroxidoek, ikatzek baino energia dentsitate handiagoa biltegiratzeko ahalmena dute. Erredox erreakzio elektrokimikoak aurkezteaz gain, kargak elektrostatikoki ere meta ditzakete. ${ }^{32}$ Superkondentsadore batean erabiltzeko egokia izateko, metal oxido batek hurrengo baldintzak bete behar ditu ${ }^{5}$ :

1. Eroankortasun egokia aurkeztu behar du.

2. Metalak, fase trantsiziorik gabe, aldi berean orekan koexistitzen diren behintzat bi oxidazio egoera izan behar ditu.

Aztertutako oxidoen artean, $\mathrm{RuO}_{2}$-arekin oso kapazitantzia balio altuak neurtu dira, ${ }^{33}$ baina bere kutsagarritasun eta prezio altuak; askoz eskuragarriagoa, merkea eta fidagarriagoa den manganeso oxidoarekin saiatzera bultzatu ditu sektoreko adituak. $\mathrm{MnO}_{\mathrm{x}}$-ekin 1100-1300 F/g-ko kapazitantzia balio teorikoak lor daitezke 10-100 nm-ko elektrodoekin, nahiz eta lodiera arruntekoekin $(\sim 100 \mu \mathrm{m})$ elektrodoekin 125-250 F/gko balioak lortzen diren. ${ }^{34-38}$

\footnotetext{
${ }^{*}$ EDCL-an

† Pseudokondentsadore batean

* Disoluzio azido edo basikoa

$\S$ Disoluzio neutroa
} 
Manganeso oxido hauek SSA altuko nanoegiturekin erraz sintetiza daitezke egitura kristalino eta morfologia ezberdinetan. Dena den, oso eroankortasun intrintseko baxua daukate, horregatik aurretiko ikerkuntzak manganesoa beste trantsizio metalekin dopatzera eta elektrodoaren lodiera minimizatzera bideratu dira. ${ }^{39}$ Eroankortasuna hobetzeko beste estrategia bat konposite bat eratzea litzateke, $\mathrm{MnO}_{2}$-a ikatz eroale batekin nahastuz ${ }^{39}$ (ikatz mesoporotsu bat, eroankortasun elektriko handikoa). Metodo honen bitartez, euskarri eroaleak 3D sare porotsua sortzea espero da ioi mugimendua errazteko, gainera $\mathrm{MnO}_{2} / \mathrm{C}$ elektrodoek 10.000 ziklo baino gehiagoko egonkortasuna aurkeztu izan dute. ${ }^{40}$ Esan bezala, $\mathrm{MnO}_{2}$ morfologia eta egitura kristalino ezberdinekin sintetiza daiteke, tratamendu termikoak, mikroemultsioen bitarteko erreakzioak eta sintesi hidrotermalak direla medio. Morfologia sakonki erlazionatuta dago SSAarekin, eta beraz, kapazitantzia espezifikoarekin, izan ere morfologia ezberdineko laginek $20 \mathrm{~m}^{2} / \mathrm{g}$-tik $150 \mathrm{~m}^{2} / \mathrm{g}$-rainoko SSA-k aurkeztu ahal dituzte. ${ }^{41}$

Orokorrean, material pseudokapazitiboei energia biltegiratzeko ahalmena ematen dieten erreakzioetan, katioiak koordinatzen dira metalarekin, honen oxidazio egoera aldatuz. Manganeso dioxidoaren kasuan, $\mathrm{H}^{+}$protoien ordezkapenagatik gertatzen da, hurrengo erreakzioaren bidez: ${ }^{41}$

$$
M n^{I V} O_{2}+x e^{-}+x H^{+} \leftrightarrow H_{x} M n^{I I I}{ }_{x} M n^{I V}{ }_{1-x} O_{2}
$$

Erredox erreakzio itzulgarri honek ematen duen energiak superkondentsadore hibridoen garapenean nolako onura ekar dezakeen aztertzeko, ikerketa lan hau proposatu da.

\section{HELBURUAK}

Ikerkuntza honen helburua superkondentsadore sistema asimetriko baten muntaketa da, $\mathrm{AC} / / \mathrm{MnO}_{2}$ gelaxka hibrido batena hain zuzen ere, elektrodo negatibotzat ikatz aktibatu bat (AC) eta elektrodo positibotzat $\mathrm{MnO}_{2} / \mathrm{C}_{\text {eroale }}$ material konposite bat erabiliz. Sistema hau eraikitzearen helburu nagusia EDLC motako AC//AC superkondentsadore batek elektrolito berdinean izango lukeen kapazitantzia espezifikoa baino balio altuagoa lortzea da. Lortu nahi den beste ituetako bat, bibliografian aurki daitezkeen beste $\mathrm{MnO}_{2}$ lagin batzuekin konparagarriak diren kapazitantzia espezifikoak lortzea da. Gainera, lan honetan elektrolito urtsuak erabiliko dira, organikoak baino tentsio baxuagoetan lan egitera behartzen dutenak, 
baina fidagarriagoak direnak erabiltzailearentzat eta ingurumenarekin inpaktu askoz lehunagoa dutenak. Horrela, hiru elektrolito ezberdin erabili dira $\left(0,5 \mathrm{M} \mathrm{Na}_{2} \mathrm{SO}_{4}\right.$, 0,5 $\mathrm{M} \mathrm{Na}_{2} \mathrm{SO}_{4}+0,2 \mathrm{mM} \mathrm{MnSO}_{4}$ eta $1 \mathrm{M} \mathrm{KOH}$ ), euren potentzial leihoa aztertuz, egokiena aukeratzeko.

AC-aren sintesia lan honen helburuetatik kanpo geratu da, eta beraz, Norit etxeko DLC Super 30 ikatz aktibatu mikroporotsua erabili da. Ez horrela $\mathrm{MnO}_{2}$ nanoegituratuaren sintesia, ingurune urtsu batean $\mathrm{KMnO}_{4}$-a etilenglikolarekin erreduzituz burutu dena. Sintetizatutako oxidoaren karakterizazio fisiko-kimikoa X-izpien difrakzioa (XRD), plasmaz induzitutako igorpen atomikoko espektroskopia (ICP-AES), mikroskopia elektronikoa (ekortze mikroskopia, SEM, eta transmisiozkoa, TEM), analisi termograbimetrikoa (TG) eta $\mathrm{N}_{2}$ adosortzio/desortzio neurketak erabiliz egin da. Gainera, 200, 300, 400, 500 eta $600{ }^{\circ} \mathrm{C}$-ko tratamendu termikoen ostean konposatuak izan dituen egituraren aldaketak aztertu dira XRD erabiliz. Bestalde, AC elektrodoaren, $\mathrm{MnO}_{2}$ elektrodoaren eta $600^{\circ} \mathrm{C}$-ra tratatutako $\mathrm{MnO}_{2}$-aren karakterizazio elektrokimikoak egin dira, hauen potentzial leiho eraginkorrak ikertuz eta euren kapazitantzia espezifikoak kalkulatuz elektrolito bakoitzean. Horretarako voltamperometria ziklikoak (CV) eta karga-deskarga galvanostatikoak (GA) burutu dira. Bukatzeko, hasieran aipatutako $\mathrm{AC} / / \mathrm{MnO}_{2}$ sistema eraiki eta bi elektrolito urtsu ezberdinetan, 0,5 $\mathrm{M} \mathrm{Na}_{2} \mathrm{SO}_{4}+0,2 \mathrm{mM} \mathrm{MnSO}_{4}$ eta $1 \mathrm{M} \mathrm{KOH}$, duen portaera elektrokimikoa aztertu da.

\section{GARAPENA}

\section{1. $\mathrm{MnO}_{2}$-AREN SINTESIA ETA KARAKTERIZAZIO FISIKO-KIMIKOA}

\subsubsection{MnO2-aren sintesia}

Ikerkuntzan lan honetan manganeso dioxido, $\mathrm{MnO}_{2}$, nanoegituratua prestatzeko jarraitutako bidea Ragupathy et al.-ek proposatutakoa izan da. ${ }^{42}$ Honetan, oxidatzaile sendoa den potasio permanganatoa, $\mathrm{KMnO}_{4}$, erreduzitzailea den etilenglikolarekin erreakzionarazten da ingurune urtsuan, nano- $\mathrm{MnO}_{2}$-a eta etilenglikolaren produktu oxidatuak (ziurrenik aldehidoak) lortzeko. Erreakzioa burutzeko, inguruko baldintzetan 0,022 mol $\mathrm{KMnO}_{4}$ komertzial (PROBUS) $200 \mathrm{~mL}$ uretan disolbatu ondoren, 0,009 mol (5 mL) etilenglikol komertzial (Panreac) gehitu zaizkio pixkanaka. 20 minutuz irabiatzen utzi da eta ondoren hutsezko iragazketa egin zaio. Lortutako 
solido marroia ur destilatuz eta etanolez garbitu eta bukatzeko labean utzi da egun batez $60{ }^{\circ} \mathrm{C}$-ra. Lortutako solidoa motrailuarekin birrindu da hauts fina lortu arte.

\subsubsection{X-izpien difrakzioa}

Karakterizazio fisiko-kimikoarekin hasteko X-izpien difrakzioa (ingelesez $x$-ray diffraction, XRD) egin zaio laginari Panalytical X'Pert PRO ekipoa erabiliz $5-70^{\circ}(2 \theta)$ tartean. Horrela, sintetizatutako $\mathrm{MnO}_{2}$-aren egitura zehaztu ahal izan da. Lortutako difraktograma eta beronen doikuntza (FullProf Suite programa paketea erabiliz) 4. Irudian erakusten dira.

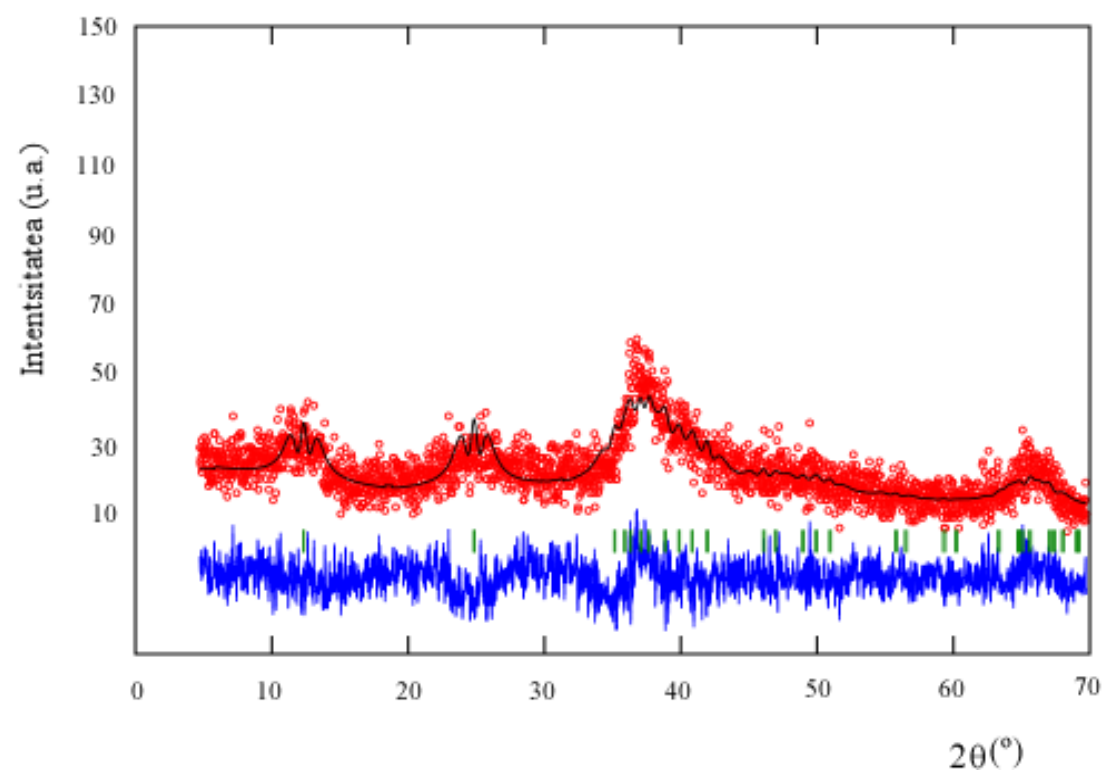

4. Irudia: $\mathrm{MnO}_{2}$ lagina birnesitarekin doitua.

Hainbat egitura kristalinorekin saiatu ondoren, difraktograma $\delta$ - $\mathrm{MnO}_{2}$-rekin (birnesita, JCPDS ${ }^{* *} 43-1456$ ) doitu da, nahiz eta altuera erdiko zabalera (ingelesez, Full widht at half maximum, FWHM) handia aurkezten duten difrakzio maximoak izan eta horrek doikuntza zailtzen duen. Egitura kristalino hau hutsune tetragonalez egindako xaflaz osatua dago, 7. Irudian ikus daitekeen moduan. Egitura laminarra egonkortu egiten da xaflen artean ioiak tartekatuz. Talde espaziala $C 2 / m$ da, eta gelaxka unitateak $a=5,174 \AA, b=2,850 \AA, c=7,336 \AA$, eta $\beta=103,18^{\circ}$ dira.${ }^{33}$ Lortutako $\chi^{2}$-a 0,989-koa izan da, baina hala ere, difraktogramaren zarata dela eta ezin da ziurtasun osoz baieztatu fasea birnesita denik (beste egitura kristalino batzuekin $\chi^{2}$ apur

*** Ingelesez Joint Committee on Powder Diffraction Standards. 
bat handiagoak lortu dira ere). Honen arrazoiak bi izan daitezke, laginaren kristalinitate maila baxua (ia amorfoa) edota partikula tamaina txikiegia izatea. Tenperaturaren igoerak difusio atomikoa erraztuko luke, kristalinitate maila handituz, horregatik egitura kristalinoago batera igarotzeko edo hasierako fase horren partikula tamaina handitzeko; 200, 300, 400, 500 eta $600{ }^{\circ} \mathrm{C}$-ko tratamendu termikoak egin zaizkio labean. Horrek FWHM txikiagoak eragingo lituzke, doikuntza erraztuz. Gainera, horrela materiala tenperatura altuagoetan izan ditzakeen aldaketak aztertu daitezke. Tenperatura bakoitzean tratatutako alikuotei XRD neurketak egin zaizkie 5. Irudian bildutako difraktogramak eskuratuz.

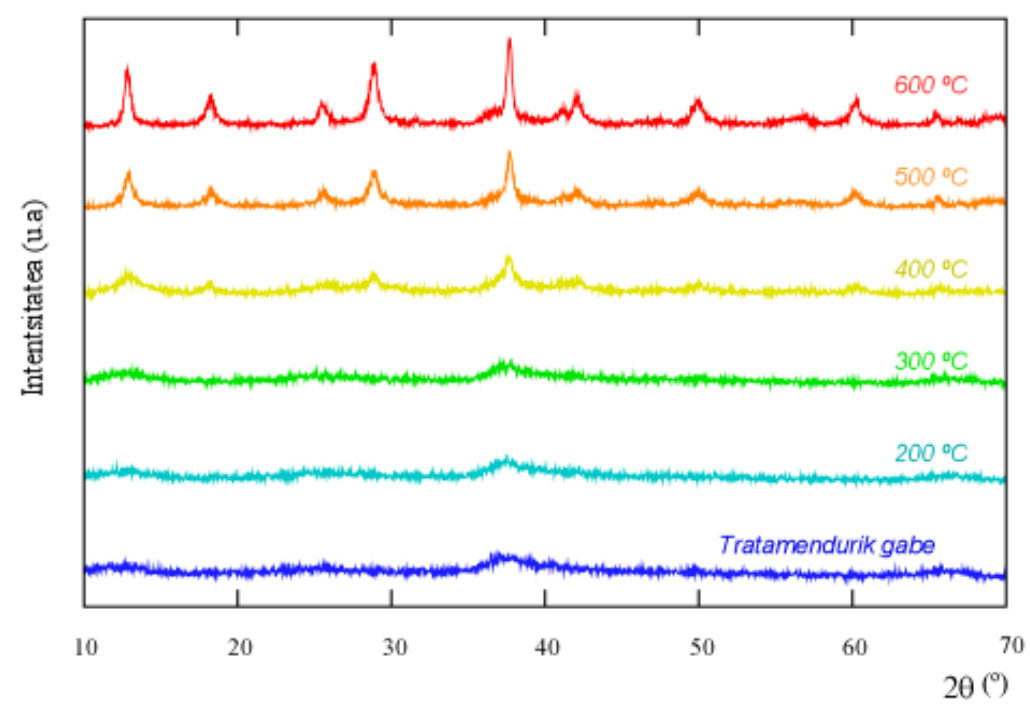

\section{Irudia: Laginaren difraktograma tratamendu termikoko tenperatura bakoitzean.}

Begi bistakoa denez, $300^{\circ} \mathrm{C}$-ra arte laginaren kristalinitate maila egonkor mantentzen da eta $400{ }^{\circ} \mathrm{C}$-tik gora bigarren fase bat bereizten hasten da. Gainera, tenperatura igo ahala seinaleak estuagoak bihurtu dira, fase berriaren kristalinitate maila altuagoa edota kristaltxoen tamaina handiagoa dela adieraziz. Azkeneko difraktogramaren doikuntzaren arabera (6. Irudia), tratamendu termikoaren ondoren, manganeso dioxidoak hutsune tetragonalez osatutako $2 \times 2$ tunel itxura duen egitura hartzen $d u, \alpha-$ $\mathrm{MnO}_{2}$ fasea hain zuzen ere (JCPDS 44-0141). Azken fase honen talde espaziala I4/m da, non $\mathrm{a}, \mathrm{b}=9,7845 \AA$ eta $\mathrm{c}=2,8630 \AA$ diren. ${ }^{33}$ 


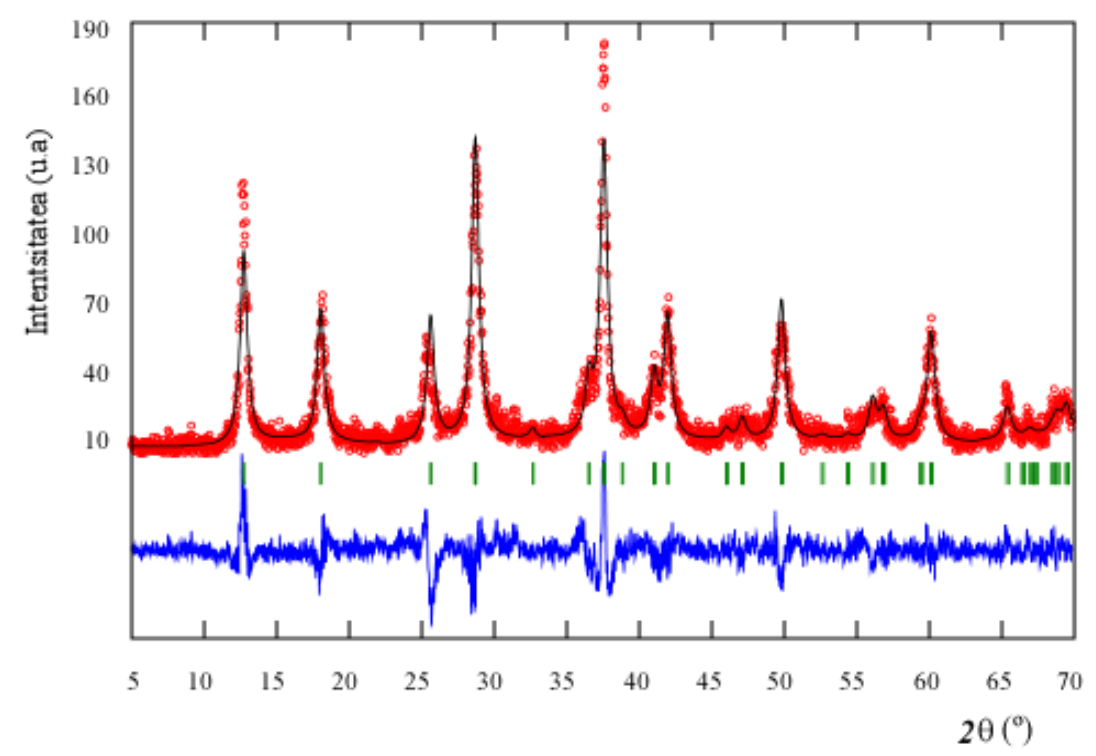

6. Irudia: $600{ }^{\circ} \mathrm{C}$-ra tratatutako laginaren doikuntza $\alpha-\mathrm{MnO}_{2}$-rekin

Beraz, 7. Irudian ikus daitekeen bezala, tratamendu termikoaren ostean sintetizatutako $\delta-\mathrm{MnO}_{2}$-a kristalinitate maila altuagoko $\alpha-\mathrm{MnO}_{2}$-a izatera pasatzen da.

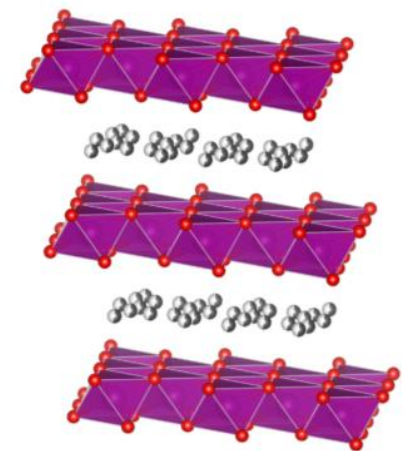

Birnesita

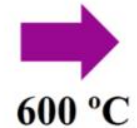

$600{ }^{\circ} \mathrm{C}$

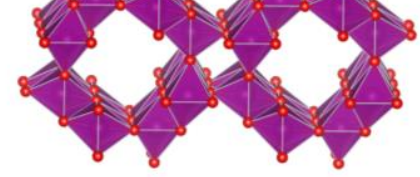

$\alpha-\mathrm{MnO}_{2}$

7. Irudia: $\mathrm{MnO}_{2}$-aren egitura kristalinoak jasaten duen aldaketa.

Egiturak portaera elektrokimikoan nolako eragina duen aztertu ahal izateko, bi lagin aukeratu dira ikerkuntzarekin jarraitzeko; alde batetik tratatu gabeko manganeso dioxidoa (lan honetan erabiliko den laburdura: $\mathrm{MnO}_{2}$ ), eta bestetik, $600{ }^{\circ} \mathrm{C}$-ra tratatu den lagina (lan honetan $\mathrm{MnO}_{2} 600$ deituko diogu). Karakterizazio fisiko-kimikoa bukatzeko, bi manganeso oxido laginei analisi termograbimetrikoa (TG), plasmaz induzitutako igorpen atomikoko espektroskopia (ICP-AES), SEM mikroskopia, TEM mikroskopia eta $\mathrm{N}_{2}$ adsortzio/desortzio neurketak egin zaizkie. 


\subsubsection{TEM eta SEM mikroskopiak}

$\mathrm{MnO}_{2}$ eta $\mathrm{MnO}_{2} 600$ laginak nanoegituratuak direla ziurtatzeko eta partikulen morfologia eta tamainak zehazteko, JEOL JSM-7000F SEM mikroskopioa erabili da. 8. Irudian ikus daitekeen bezala, partikula oso txikiz osatutako $1 \mu \mathrm{m}$-tik beherako partikula aglomeratuak behatzen dira bi kasuetan. Partikulen tamaina txikia dela eta mikroskopia teknika honen bereizmena ez dena nahikoa, eta beraz, handipen handiagoko Philips CM200 ekipoarekin TEM mikroskopia burutu da.
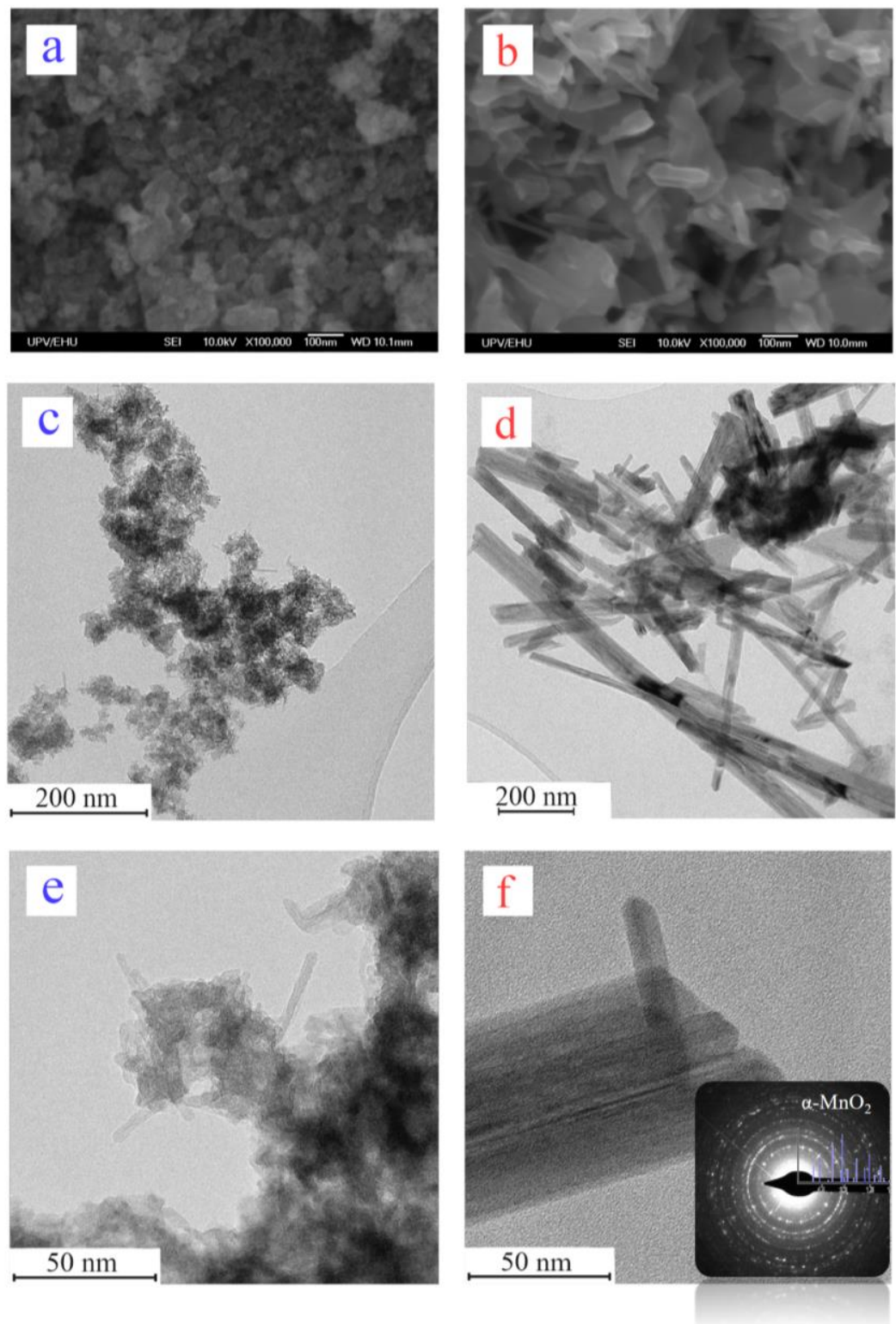

8. Irudia: (a) $\mathrm{MnO}_{2}$-aren SEM irudia. (b) $\mathrm{MnO}_{2}$ 600-aren SEM irudia. (c eta e) $\mathrm{MnO}_{2}$-aren TEM irudiak. (d eta f) $\mathrm{MnO}_{2}$ 600-aren TEM irudiak. $\mathrm{MnO}_{2}$-600-aren elektroi difrakzio patroia (f)-ren barruan sartu da. 
Dena den, begi bistaz ondorioztatu daiteke 8.b Irudiko partikulen tamaina $\left(\mathrm{MnO}_{2} 600\right)$ 8. a Irudian agertzen direnena $\left(\mathrm{MnO}_{2}\right)$ baino handiagoa dela. TEM argazkiek erakusten dutenez, $\mathrm{MnO}_{2}$ lagina ordenamendurik gabeko 3 - $4 \mathrm{~nm}$-ko zabalera duten orratz eta maluta (flake) itxurako nanopartikulen aglomeratuz osatua dago. Horrez gain, tratamendu termikoak sinterizaziorik eragin ez duela ikus daiteke. $\mathrm{MnO}_{2} 600$ lagina 25 - 75 nm-ko kristal azikularrez osatutako taldeetan antolatuta dago, eta nahiz eta partikula-tamaina handitu den, ez da partikulen arteko aglomeraziorik gertatu. Tratamendu gabeko laginak nanopartikula txikiagoak dituenez, SSA askoz handiagoa izatea espero da. Hau egiaztatzeko, $\mathrm{N}_{2}$ adsortzio/desortzio neurketen bitartez gainazal espezifikoa kalkulatu da. Bestalde, 8.f Irudian ageri den elektroi difrakziozko patroiaren doikuntzak, XRD bitartez ondorioztatu dena berresten du, $\mathrm{MnO}_{2} 600$ laginak $\alpha-\mathrm{MnO}_{2}$ egitura duela.

\subsection{4. $\mathrm{N}_{2}$ adsortzio/desortzioa}

Laginen adsortzio/desortzio ahalmena, SSA-rekin zuzenki erlazionatuta dago, eta azken hau beraien propietate elektrokimikoekin. Izan ere, elektrodo pseudokapazitiboak diren konposatuetan erredox erreakzioak gainazalean gertatzen dira, eta beraz, azalera espezifiko altuak kapazitantzia balio altuagoak lortzen lagun dezake. Manganeso dioxidozko bi laginen SSA balioak $\mathrm{N}_{2}$ adsortzio/desortzio neurketen bitartez lortutako datuetatik kalkulatu dira BET (Brunauer-Emmett-Teller) teoria erabiliz. Horretarako, Quantachrome AutosorbIQ ekipoa erabili da, inguru tenperaturan eta $273 \mathrm{~K}$-etan. Hasierako desgasifikazioa laginak 3 orduz $80{ }^{\circ} \mathrm{C}$-tan eta hutsean $\left(10^{-4}\right.$ bar $)$ mantenduz egin da. Bi laginetan adsorbatutako $\mathrm{N}_{2}$ bolumenak $\mathrm{MnO} 2$ lagina, bere ahaideak baino partikula tamaina txikiagoa duela eta horrek azalera espezifiko altuago batean islatu daitekela. 9. Irudian bildu dira. 


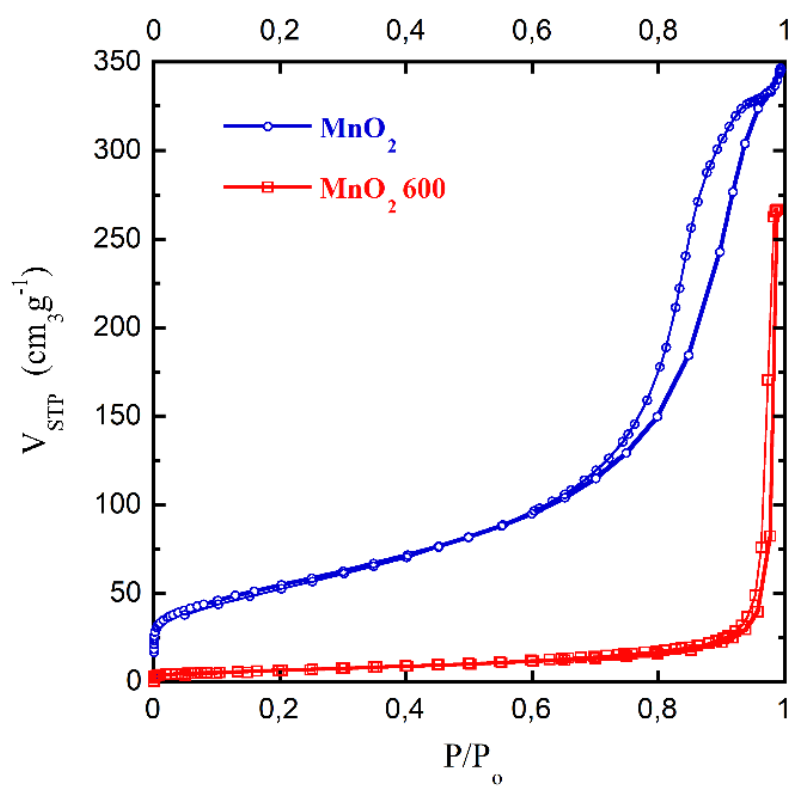

9. Irudia: Adsortzio/desortzio isotermak $\mathrm{MnO}_{2}$ eta $\mathrm{MnO}_{2} 600$ laginentzat.

$\mathrm{MnO}_{2}$ laginak, IUPAC-ren arabera, IV motako isoterma lortu du. Isoterma mota hau, $\mathrm{P} / \mathrm{P}^{0}$ balio txikietan monogeruza baten formakuntza azaltzen $\mathrm{du}$, interakzio ahulagoko multigeruzen agerpenaz jarraitua, eta $\mathrm{P} / \mathrm{P}^{0} 0,7$ balioetatik aurrera agertzen den histeresi kurba mesoporoen existentziarekin erlazionatuta egon daiteke. Bestalde, $\mathrm{MnO}_{2} 600$ laginak III motako isoterma lortu du, x ardatzarekiko konbexua dena eta adsorbatoadsorbatzaile afinitate baxuarekin erlazionatua dagoena, hasiera batetik auzazko multigeruzen eraketa adierazi dezakeena. ${ }^{43}$ BET metodoaren arabera kalkulatutako SSA-k hurrengoak dira: $197 \mathrm{~m}^{2} / \mathrm{g}$ tratatu gabeko laginean eta askoz txikiagoa den $24 \mathrm{~m}^{2} / \mathrm{g} 600^{\circ} \mathrm{C}$-tan tratatutakoarentzat. Beraz, emaitza hauek bat datoz XRD eta TEM mikroskopiaren bidez eratorritako ondorioekin. $\mathrm{MnO}_{2}$ lagina, bere ahaideak baino partikula tamaina txikiagoa duela eta horrek azalera espezifiko altuago batean islatu daitekela.

\subsubsection{Analisi termograbimetrikoa}

Laginen konposizioa zehazteko analisi termograbimetriko diferentziala burutu da Netzsch STA $449 \mathrm{C}$ ekipo batean, $5^{\circ} \mathrm{C} / \mathrm{min}$ beroketa abiadurarekin, $800{ }^{\circ} \mathrm{C}$-raino eta Ar atmosferan. 10. Irudian ikus daitezke $\mathrm{MnO}_{2}$ eta $\mathrm{MnO}_{2} 600$ laginentzat lortutako emaitzak. 


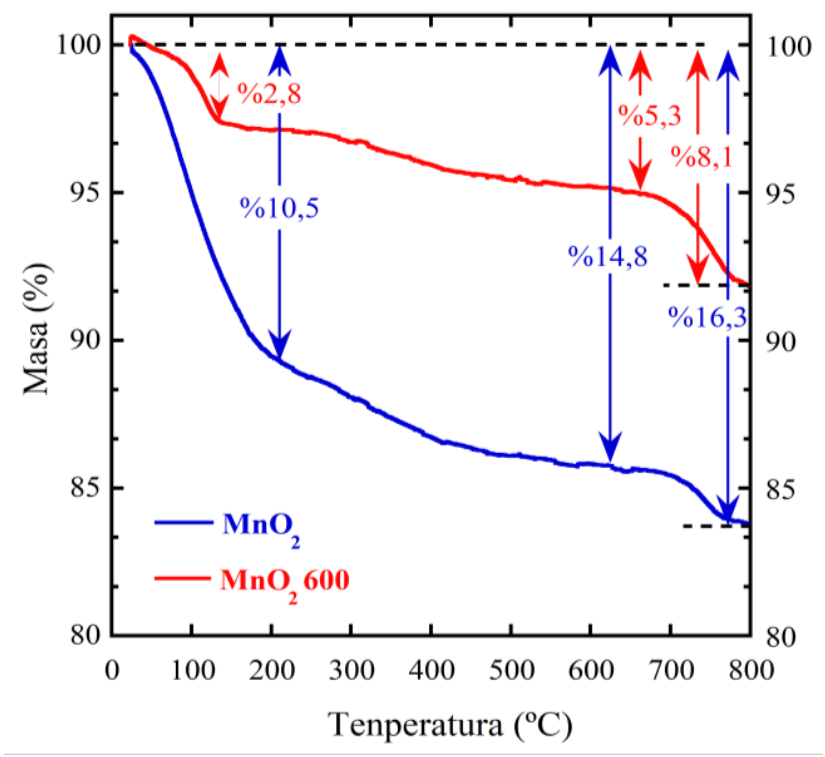

10. Irudia: Bi laginen masa galerak tenperatura igotzean.

Orohar, $\mathrm{MnO}_{2}$-ren kasuan masa galera $\mathrm{MnO}_{2} 600$ laginaren kasuan baino handiagoa da, \% 16,3 vs. \% 8,1, hurrenez hurren. Bi kasuetan, 100 eta $200{ }^{\circ} \mathrm{C}$ bitartean adsorbatutako ur molekulei dagokien masa galera ikusi da. Espero bezala, termikoki tratatu gabeko laginaren galera $\mathrm{MnO}_{2} 600$ laginarena baino askoz handiagoa izan da (\% 10,5 vs. \% 2,8), izan ere, lehenengoaren SSA handiagoa izanik ur molekula gehiago adsorba ditzake. Ondoren, $200-600{ }^{\circ} \mathrm{C}$ bitartean, bietan \% 2 - 4-ko galera behatu da. $\mathrm{MnO}_{2}$-an, \% 4,3-ko galera hori barne egiturako urari dagokio, beraz, egituraren berrantolaketa bat gertatu denaren seinale da $\left(\delta-\mathrm{MnO}_{2}\right.$-tik $\alpha-\mathrm{MnO}_{2}$-ra hain zuzen ere), birnesitaren egitura laminarraren desegonkortzeagatik. ${ }^{44,45} \mathrm{MnO}_{2} 600$ laginean aldiz, tratamendu termikoan jada barne egiturako ur molekula horiek galdu izan dituenez, galdutako \% 2,5 hori Valente et al.-ek dioten moduan, adsorbatutako $\mathrm{CO}_{2}$ molekulen askapenaren ondoriozkoa izan daiteke. ${ }^{46}$ Ostera, $600-800^{\circ} \mathrm{C}$ tartean, hirugarren masa galera bat ageri da bietan, (tenperatura horretan bi laginak $\alpha-\mathrm{MnO}_{2}$ fasekoak dira), ziur aski Mn(IV)-aren erredukzio partzialagatik gertatzen den oxigenoaren askapenari dagokiona. ${ }^{45}$

Bestalde, laginak lortzeko sintesia potasio permanganatotik abiatzen denez, bi laginen egituran dagoen potasioaren kantitatea zehazteko ICP-AES neurketak burutu dira Agilent Technologies 5100 instrumentua erabiliz. Horretarako, lagin bakoitzeko 3 disoluzio independente prestatu eta analizatu dira. Kalkulatutako K:Mn erlazio 
atomikoak 0,27:1 $\left(\mathrm{MnO}_{2}\right)$ eta 0,26:1 $\left(\mathrm{MnO}_{2} 600\right)$ izan dira. Beraz, bi laginetan potasioa dagoela eta tratamendu termikoak potasio atomoen presentzian eragina ez duela frogatu ahal izan da. Datu hauek, TG-an lortutako masa galerekin batera, bi laginen formula zehatzak lortzea ahalbidetu du: $\mathrm{K}_{0,27} \mathrm{MnO}_{2} \cdot 0,27 \mathrm{H}_{2} \mathrm{O}$, tratatu gabeko laginean, eta $\mathrm{K}_{0,26} \mathrm{MnO}_{2}, 600{ }^{\circ} \mathrm{C}$-ra tratatutakoan.

Qu et al.-ek beren ikerketetan azaltzen duten moduan $\mathrm{K}: \mathrm{Mn}$ erlazio hau duten $\delta-\mathrm{MnO}_{2}$ laginek, $\mathrm{K}^{+}$ioiak eta ur molekulak dituzte pilare moduan xaflen artean egitura kristalinoa egonkortzen laguntzeko. Gainera, ikerketa horietan 10000 karga/deskarga ziklo baino lehen eta ondoren egindako XRD difraktogramen parekotasunetik, ziklatzean egitura kristalinoan ia aldaketarik gertatzen ez dela ondorioztatzen da. ${ }^{47}$

\section{2 $\mathrm{MnO}_{2}$-EN ETA AC-AREN KARAKTERIZAZIO ELEKTROKIMIKOA}

\subsubsection{Elektrodoen ekoizpena}

Aurretik esan bezala, laginaren tratamendu termikoak, eta beraz laginaren egiturak, elektrokimikan duen eragina aztertzeko, ikerkuntza honetan erabilitako elektrodo positiboen material aktiboak $\mathrm{MnO}_{2}$ edo $\mathrm{MnO}_{2} 600$ izan dira, eta negatiboena, aldiz, NORIT DLC Super 30 ikatz aktibatu (AC) komertziala (SSA $1600 \mathrm{~m}^{2} / \mathrm{g}$ ). Elektrodo positiboetan erabili den konposizio zehatza hau izan da: \% 70 material aktiboa, \% 20 SUPER C65 (Timcal) ikatz eroalea -oxidoaren eroankortasun faltaren arazoan laguntzen duena-, eta \% 10 politetrafluoroetileno (PTFE) aglomeratzailea (Sigma Aldrich, pisuan \% 60 disoluzio urtsua). Elektrodoak ekoizteko prozesua hurrengoa izan da: (i) lagina eta C65 ikatzaren masa zehatzak pisatu eta hauek motrailuarekin homogeneizatu dira. (ii) Nahastea bir-pisatu eta PTFE kantitate zehatza gehitu zaio. (iii) Nahaste solidoari etanola gehitu zaio eta guztia homogeneizatzeko espatularen laguntzaz irabiatu da. Homogeneizatzen den heinean, plastikotasuna irabazten du. (iv) Nahastura beltzak nahi den trinkotasun eta testura daukanean, geruza finaren forma eman $(\sim 150 \mu \mathrm{m})$ eta $80^{\circ} \mathrm{C}$-tan lehortu egin da gau batean zehar. Lortutako geruza finari laminatu deritzo, eta honen lodieraren arabera elektrodoek izango duten masa ondorioztatu daiteke. (v) Bukatzeko, laminatua $11 \mathrm{~mm}$-ko diametroko elektrodo zirkularretan moztu da. AC elektrodoak prestatzeko burututako prozesua berdina izan da, baina kasu honetan konposizioa \% 95 AC eta \% 5 PTFE izan da. 


\subsubsection{Elektrodoen karakterizazio elektrokimikoa}

Sistema finalerako elektrolito egokiena zein den aztertzeko hiru elektrolito urtsu prestatu dira: $0,5 \quad \mathrm{M} \quad \mathrm{Na}_{2} \mathrm{SO}_{4}$ (lan honetan $\mathrm{Na}_{2} \mathrm{SO}_{4}$ deituko zaio), 0,5 $\mathrm{M} \mathrm{Na}_{2} \mathrm{SO}_{4}+0,2 \mathrm{mM} \mathrm{MnSO}_{4}(\mathrm{NaMn})$ eta $1 \mathrm{M} \mathrm{KOH}(\mathrm{KOH})$. Erabilitako hiru erreaktiboak Sigma Aldrich etxe komertzialekoak izan dira. Aipatutako bigarren elektrolitoan, NaMn-n, 0,2 mM $\mathrm{MnSO}_{4}$ erabili dira disoluzioan $\mathrm{Mn}^{2+}$ kontzentrazio txikia izateak $(0,2-1 \mathrm{mM}) \mathrm{MnO}_{2}$ motako elektrodoen portaera elektrokimikoa hobetzen laguntzen duela frogatu delako. Ikusi denez, elektrolitoko $\mathrm{Mn}^{2+}$ ioien oxidazio elektrokimikoa dela eta elektrodoaren gainean nanogeruza porotsuak jalki eta, ondorioz, ziklabilitatea eta ahalmen kapazitiboa hobetzen dira. ${ }^{48}$ Elektrolito hauek elektrodo bakoitzaren elektrokimikan daukaten eragina aztertzeko, hiru elektrodotako Swagelok® gelaxkak eraiki dira. Horietan, lan-elektrodo gisa $\mathrm{MnO}_{2}$ eta $\mathrm{MnO}_{2} 600$ edo $\mathrm{AC}-\mathrm{a}$ erabili dira, kontra-elektrodo moduan $\mathrm{AC}-\mathrm{a}$, erreferentzia gisa $\mathrm{Ag} / \mathrm{AgCl}$ (Metrohm, 3M KCl) elektrodo bat eta elektrolito moduan aurretik aipatutako disoluzioak. Analisi elektrokimikorako voltamperometria ziklikoak burutu dira (ingelesez cyclic voltammetry, CV), BioLogic VMP3 potentziostato/galvanostatoan. CV-ak 5, 10, 20, 50, 100 eta 200 mV/s-ko ekorketa abiaduretan (v) egin dira, eta elektrolitoa eta materialaren arabera potentzial leiho ezberdin batean. $\mathrm{Na}_{2} \mathrm{SO}_{4}$ elektrolitoan lortutako emaitzak 11. Irudian azaltzen dira. Orokorrean ikus daitekeen moduan, ekorketa abiadura igo ahala, sistemak korronte intentsitate handiagoak lortzen ditu (11. Irudiaren eskumaldea), baina erresistentziak gora egiten duenez kapazitantzia balioak txikitu egiten dira (11. Irudiaren ezkerraldea). 

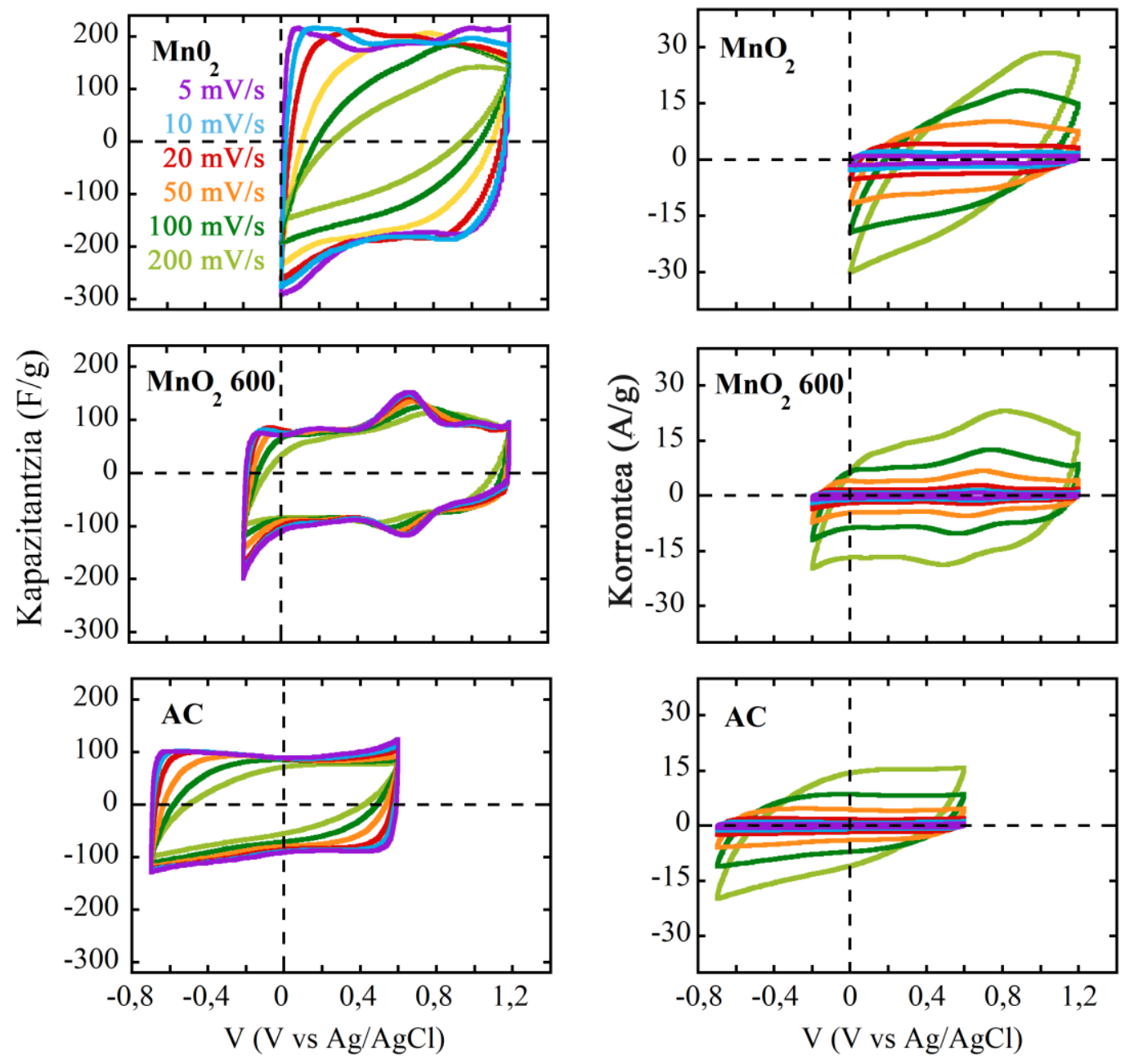

11. Irudia: $\mathrm{CV}$-en emaitzak 0,5 $\mathrm{M} \mathrm{Na}_{2} \mathrm{SO}_{4}$ elektrolitoan.

Manganeso dioxidoei dagokienez, lortutako potentzial leihoak potentzial balio positiboagoetan $(-0,1-1,2 \mathrm{~V})$ daude AC-arekin konparatuz $(-0,7-0,7 \mathrm{~V})$, espero zen bezala, lagin oxidoak elektrodo positibo gisa erabiltzeko egokiagoak direla baieztatuz. Bestalde, nahiz eta $\mathrm{MnO}_{2} 600$ laginean potentzial leihoa apur bat zabalagoa izan, $\mathrm{MnO}_{2}$ laginekin kapazitantzia balio altuagoak lor daitezke erabilitako elektrolitoan. Dena den, tratatu gabeko lagineko elektrodoan ekorketa abiadura igotzean, proportzionalki, kapazitantzia balioak $600{ }^{\circ} \mathrm{C}$-ko laginean baino askoz gehiago txikitzen dira. Azken horretan, kapazitantzia egonkorragoa da, hortaz, abiadura handitzean $\mathrm{MnO}_{2}$-ak erresistentziaren kontribuzio handiagoa aurkezten duela esan daiteke. Lortutako kapazitantzia espezifiko maximoak ekorketa abiadura bakoitzean 14. Irudian ikus daitezke. Ikerketako hurrengo elektrolitoaren emaitzak, NaMn-renak, 12. Irudian agertzen dira. 

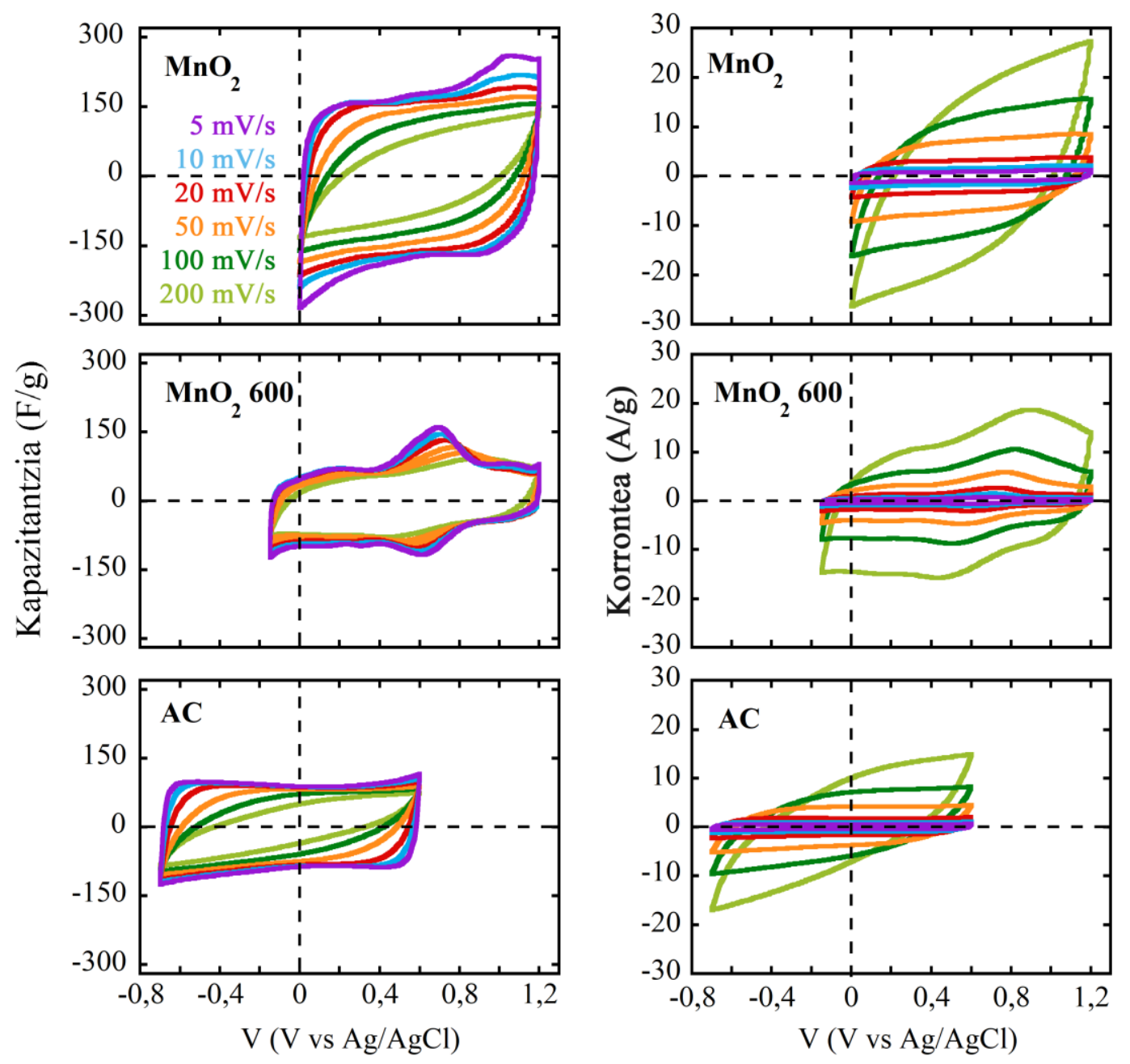

12. Irudia: $\mathrm{CV}$-en emaitzak 0,5 $\mathrm{M} \mathrm{Na}_{2} \mathrm{SO}_{4}+0,2 \mathrm{mM} \mathrm{MnSO}_{4}$ elektrolitoan.

Kasu honetan lortutako potentzial leihoak aurreko elektrolitoarekin lortutakoen oso antzekoak dira $( \pm 0,1 \mathrm{~V})$, beraz, $\mathrm{Mn}^{2+}$ katioien presentziak ez du eragin handirik parametro honetan. Kapazitantziari dagokionez aldiz, AC eta $\mathrm{MnO}_{2} 600$ laginen kasuan, $\mathrm{Na}_{2} \mathrm{SO}_{4}$ elektrolitoan baino balio baxuagoak lortzen direla behatu da, baina $\mathrm{MnO}_{2}$ laginarekin, ordea, alderantziz gertatzen da. Azken kasu honetan, 180 F/g-ko kapazitantzia maximoa lortu da, $\mathrm{Na}_{2} \mathrm{SO}_{4}$ elektrolitoan baino \% 61 altuagoa (ikusi 14 . Irudia). Hortaz, bi oxido laginen eta bi elektrolito hauen artean ahalmen kapazitibo handiena duen konbinazioa $\mathrm{MnO}_{2}$ elektrodoa $\mathrm{NaMn}$ elektrolitoan da. Aipagarria da ere bi elektrolitoetan AC-arekin lortzen diren $\mathrm{CV}$ karratuak, perturbazio handirik gabekoak, portaera kapazitibo puruaren seinale direnak (EDLC-ena hain zuzen). Oxidoek, aldiz, gorabehera gehiagoko CV irregularragoak ematen dituzte, erredox erreakzioek sortuak (portaera pseudokapazitiboa). ${ }^{19}$ Sulfato elektrolitoez gain, $\mathrm{KOH}$ 
elektrolitoan lortu diren emaitzek desberdintasun handiagoak erakutsi dituzte, 13. Irudian erakusten den moduan.
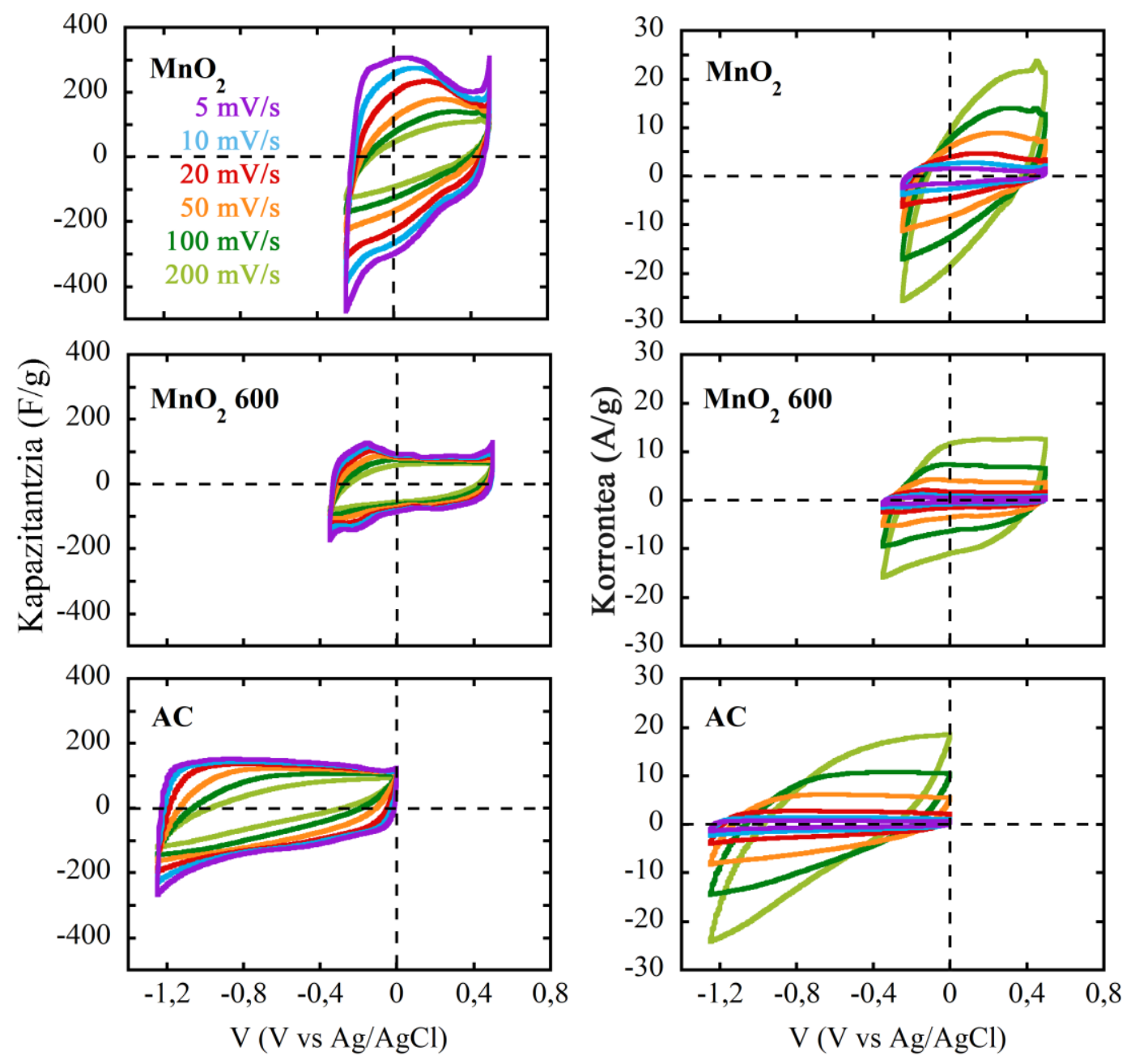

13. Irudia: CV-en emaitzak $1 \mathrm{M} \mathrm{KOH} \mathrm{elektrolitoan.}$

Elektrolito honetan ere, AC-arekin alderatuz manganeso dioxidozko bi elektrodoek potentzial leiho positiboagoa lortu dute, baina oraingoan potentzial balio negatiboetarantz desplazatutako leiho estuagoak lortu dira orokorrean. Bere ahaidearekin konparatzen badugu, $\mathrm{MnO}_{2}$ laginak $0,2 \mathrm{~V}$ txikiago den potentzial tartean lan egin duela ikus daiteke, eta balio absolutuan 0,8 V-ko leihoa lortu du. Beste bi elektrolitoekin eskuratutako 1,2 V-ko leihoekin alderatuz eta 1. Ekuazioa jarraituz gero, elektrolito honetan materialak energia dentsitate txikiago biltegiratu dezakeela pentsa daiteke potentzial leiho txikiagoan lan egiten baitu. Baina leihoaren murrizpena, kapazitantzia balio altuagoekin konpentsatzen da, $\mathrm{MnO}_{2}$-ak 237 F/g-ko 
kapazitantzia espezifiko maximoa lortu baitu. Beste elektrolitoekin alderatuta, AC elektrodoaren kasuan ere kapazitantzia balio altuagoak aurkitu dira, $\mathrm{MnO}_{2}$ 600-ean antzekoak izan diren bitartean. Lortutako CV-en itxurari dagokionez, aurreko kasuetan bezala, AC-ak material kapazitibo idealetik hurbil dagoen profila aurkezten duen bitartean beste bi laginek erredukzio eta oxidazio prozesuen seinale diren maximoak (edota minimoak) aurkezten dituzte.
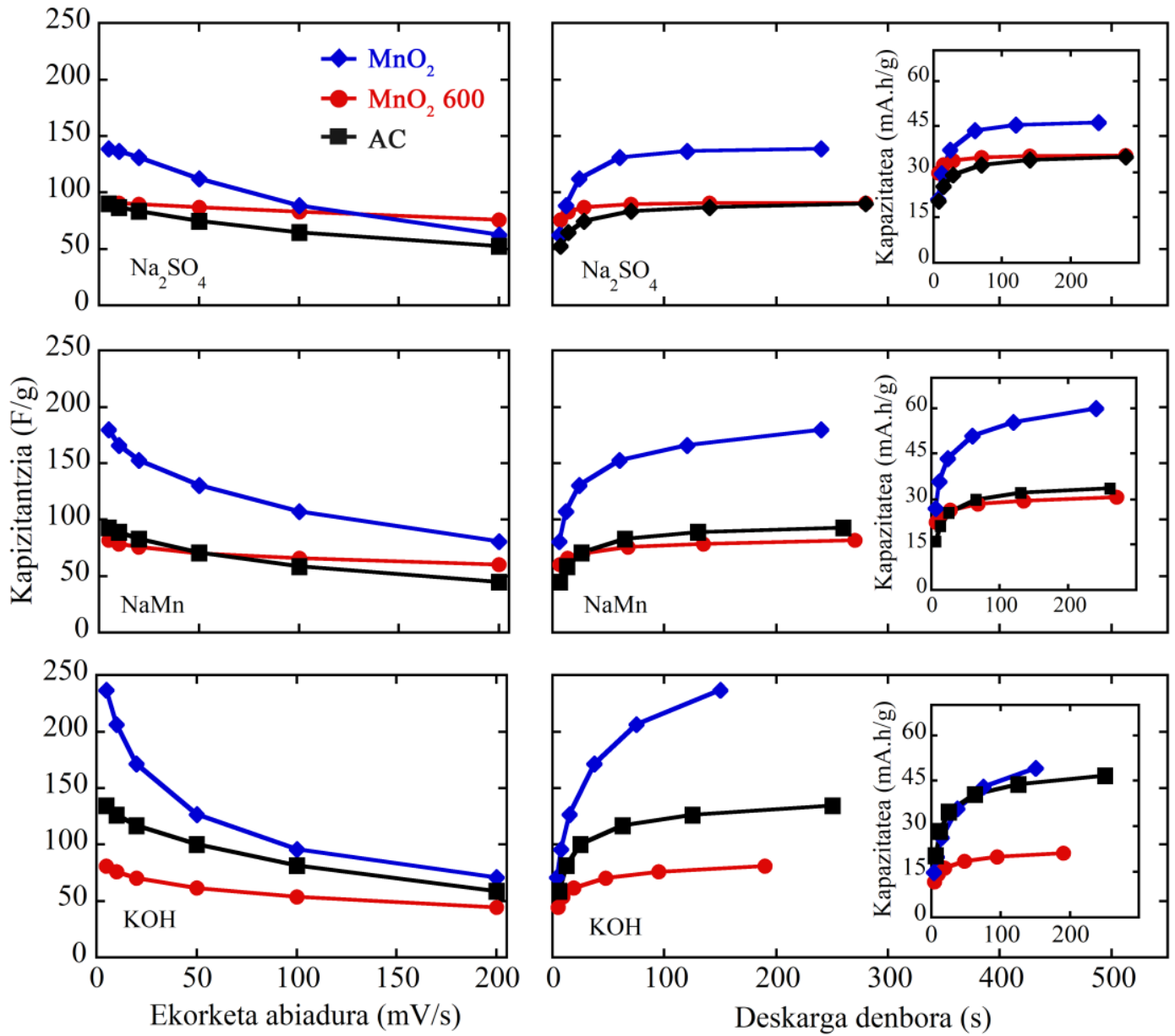

\section{Irudia: Ezkerraldean, elektrolito bakoitzean 3 laginen kapazitantzia espezifikoak ekorketa abiadurarekiko. Eskuinaldean, kapazitantzia eta kapazitate espezifikoak deskarga denboraren arabera.}

Elektrodo bakoitzaren eraginkortasuna hobeto konparatu ahal izateko, 14. Irudian ekorketa abiadura bakoitzean kalkulatutako kapazitantzia espezifikoak bildu dira. Aurretik aipatu den moduan, kapazitantzia balio altuenak $\mathrm{MnO}_{2}$ laginak $\mathrm{KOH}$ elektrolitoan lortu ditu (237 F/g). Baina aurretik azaldu den bezala, 1. Ekuazioa jarraituz, energia biltegiratzeko ahalmena potentzial leihoarekin ere erlazionatua dago, 
eta tarterik handiena NaMn elektrolitoan lortu du lagin honek (1,2 V vs. 0,8 V). $600{ }^{\circ} \mathrm{C}$-ra tratatutako bere ahaideak, antzeko potentzial leihoetan eman du erantzun elektrokimikoa eta kapazitantzia espezifikori dagokionez balio baxuagoak aurkeztu ditu elektrolito guztietan. Hortaz, elektrodo positiborako $\mathrm{MnO}_{2}$ lagina egokiagoa dela pentsa daiteke. Horretaz aparte, AC elektrodoak, elektrodo negatiboaren funtziorako proposatu dena, joera berdina aurkeztu du: kapazitantzia balio altuagoak lortu ditu $\mathrm{KOH}$ elektrolitoan baina potentzial leiho zabalagoak NaMn elektrolitoan. Hortaz, bi sistema final ezberdin prestatuko dira, bietan $\mathrm{MnO}_{2}$ lagina elektrodo positiboa izango da eta elektrodo negatiboa, berriz, AC-a, baina elektrolitoari dagokionez sistema batean NaMn elektrolitoa erabiliko da eta bestean $\mathrm{KOH}$.

\subsection{SISTEMA FINALAREN KARAKTERIZAZIO ELEKTROKIMIKOA}

Sistema finalean, aurretik aipatu den moduan, $\mathrm{MnO}_{2}$ elektrodoa erabiliko da elektrodo positibo modura, eta AC, aldiz, elektrodo negatibo gisa. Bi elektrolito ezberdinetan aztertuko da sistema, $\mathrm{KOH}$ eta NaMn-n. Sistema hibrido hau, oraingoan bi elektrodoko konfiguraziorako Swagelok gelaxka batean eraiki da, erreferentzia elektrodorik gabe, beraz analisi elektrokimikoetan gelaxka osoaren tentsioa (V) neurtuko da. Sistema asimetriko honetan ahalik eta eraginkortasun altuena lortzeko,4. eta 5. Ekuazioetan azaldutako masa balantzea egin behar da. Kapazitateak elektrodo masa unitate bakoitzeko, metatu edo askatutako karga adierazten duenez, 14. Irudian ere parametro hau deskarga denborarekiko irudikatu da. Bertan ikus daiteke NaMn elektrolitoan, $\mathrm{MnO}_{2}$ elektrodoak, deskarga denbora oso txikietan izan ezik, orokorrean AC-aren kapazitate bikoitza aurkezten duela; ondorioz, sistema finalerako onena AC-ko elektrodoak masa bikoitza izatea da, hots, $\mathrm{AC}: \mathrm{MnO}_{2} 2: 1$ masa balantzea egitea. $\mathrm{KOH}$ elektrolitoan, aldiz, bi elektrodoek pareko kapazitate balioak erakusten dituzte aztertutako deskarga denbora tarte guztian, beraz, 1:1 masa balantzea erabiliko da kasu horretan. Hasteko, elektrolito bakoitzerako sistemaren tentsio eraginkorra zein den aztertu da CV-en bitartez. Gainera, 15. Irudian ikusten denez, CV-en profil karratua superkondentsadore batentzako espero genukeena da, ekorketa abiadura handitzearekin apur bat distortsionatzen dena. Behin gelaxken tentsioa ezaguna denean, karga/deskarga galvanostatikoak, (ingelesez galvanostatic charge/discharge, GA charge/discharge) erabili dira gelaxka tentsio horietan, kapazitantzia espezifikoa kalkulatzeko. GA karga/deskargetan erabilitako korronte dentsitateak 0,1, 0,5, 0,7, 1 , 
$2,5,7,10,12$, eta $15 \mathrm{~A} / \mathrm{g}$ izan dira. Sistema mota bakoitzeko birritan egin dira neurketak, sistemaren funtzionamendu egokia ziurtatzeko, eta emaitzak 15. Irudian bildu dira.
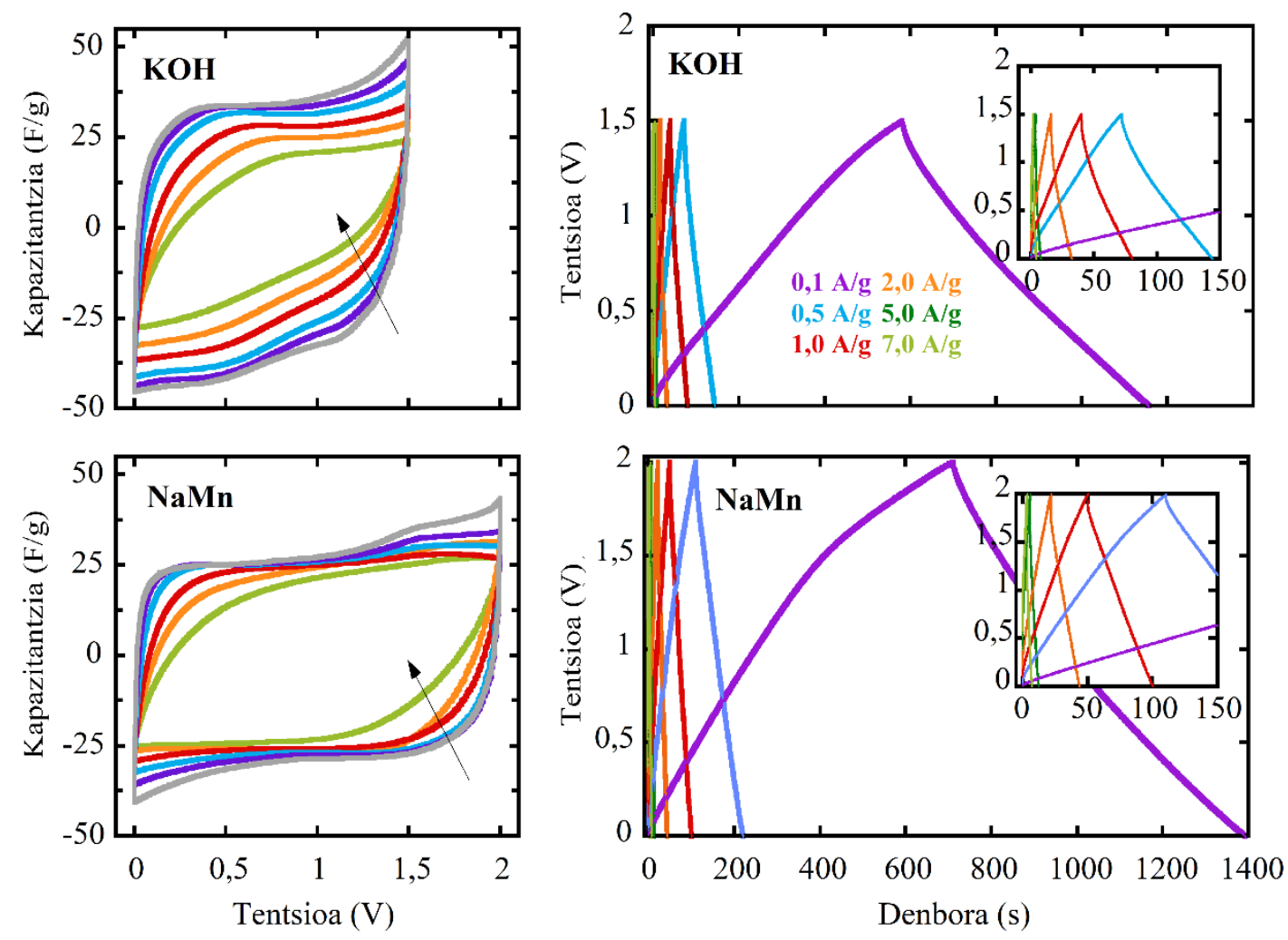

15. Irudia: Ezkerrean, KOH eta NaMn elektrolitoen neurtutako CV-ak, 5, 10, 20, 50, 100 eta $200 \mathrm{mV} / \mathrm{s}$-tan. Eskuinean, GA karga/deskargen profilak aipatutako elektrolitoetan.

Aipatutako irudian ikusten denez, GA karga/deskarga profilak linealak dira eta erabilitako korronte dentsitate guztietan. Banakako elektrodoen ikerketan bezala, NaMn elektrolitoan potentzial leiho handiagoak lortu ziren pareko moduan, elektrolito honetan lan egin duten gelaxkek tentsio handiagoak lortu dituzte, $2 \mathrm{~V}$-koak hain zuzen ere. $\mathrm{KOH}$ elektrolitoko gelaxkak tentsio baxuagoan lan egin dutenez, 1. Ekuazioari berriro erreparatuz, energia dentsitate baxuagoak biltegiratuko dituela esan genezake kapazitantzia balioak apur bat altuagoak izan arren.

CV hauetan gelaxka bakoitzeko elektrodo positibo eta negatiboen portaera 16. Irudian irudikatu da, zeinetan behatu daitekeen nola masa balantzeak elektrodoen leihoetan eragina izan duen. 

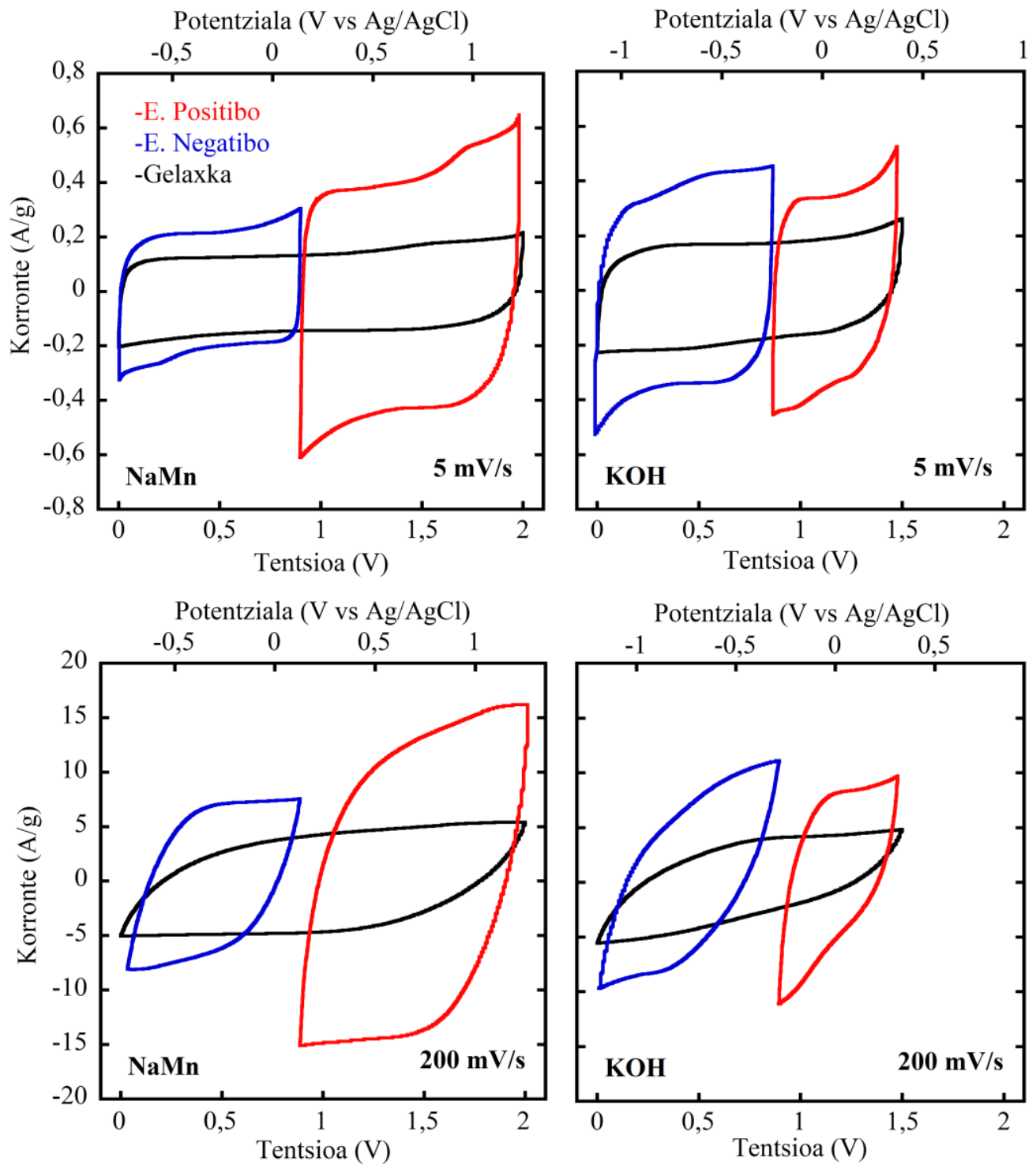

16. Irudia: Elektrodoen CV-ak $5 \mathrm{mV} / \mathrm{s}$ eta $200 \mathrm{mV} / \mathrm{s}$-ra.

NaMn elektrolitoan, elektrodo negatiboaren funtzionamendu potentzial tartea $-0,7-0,2 \mathrm{~V}$ vs. $\mathrm{Ag} / \mathrm{AgCl}$ izan da eta positiboarena $-0,2-1,4 \mathrm{~V}$ vs. $\mathrm{Ag} / \mathrm{AgCl}$. 12. Irudian lortutako leihoekin alderatuta apur bat txikiagoak izan dira, beraz, baliteke gelaxkaren tentsioa handitu ahal izatea masa balantzea apur bat aldatuz. Bestalde, behatu daiteke elektrodo positiboak korronte espezifiko balio handiagoak lortzen dituela, negatiboaren masa erdia baitu, 2:1 masa balantzea dela eta. KOH elektrolitoan berriz, elektrodo negatiboak -1,1 - 0,25 V vs. Ag/AgCl-ko potentzial diferentzian lan egin du eta positiboak $-0,25-0,4 \mathrm{~V} v s$. $\mathrm{Ag} / \mathrm{AgCl}$ tartean. Berriro ere banakako elektrodoen azterketan baino potentzial leiho estuagoak erabili dira 13. Irudiarekin 
konparatzen bada. Beraz, baliteke zehaztutako gelaxka tentsioak zabaltzea posible izatea eraginkortasuna hobetzeko. Aipatu beharrekoa da ere, bi elektrolitoetan, ekorketa abiadura edozein izanda ere elektrodo bakoitzaren funtzionamendu potentzial tartea aldatzen ez dela.Gelaxkaren tentsioaz gain, sistemak biltegiratu dezakeen energia dentsitatea jakiteko, kapazitantzia balioak ere aztertu behar dira. Karga eta deskarga GA-ek sistema batek karga kantitate zehatz bat biltegiratzeko edota askatzeko zenbat denbora behar duen jakitea ahalbidetzen dute. Beraz, aplikatutako korrontea ezaguna denez 8. Ekuazioak erakusten duen moduan, sistemaren kapazitantzia kalkulatzea posiblea da.

$$
C=\frac{Q}{V} \stackrel{Q}{Q} \stackrel{I . t}{\rightarrow} C=\frac{I . t}{V}
$$

Bi sistemetan korronte dentsitate bakoitzerako lortutako kapazitantzia balioak 17. Irudian bildu dira.

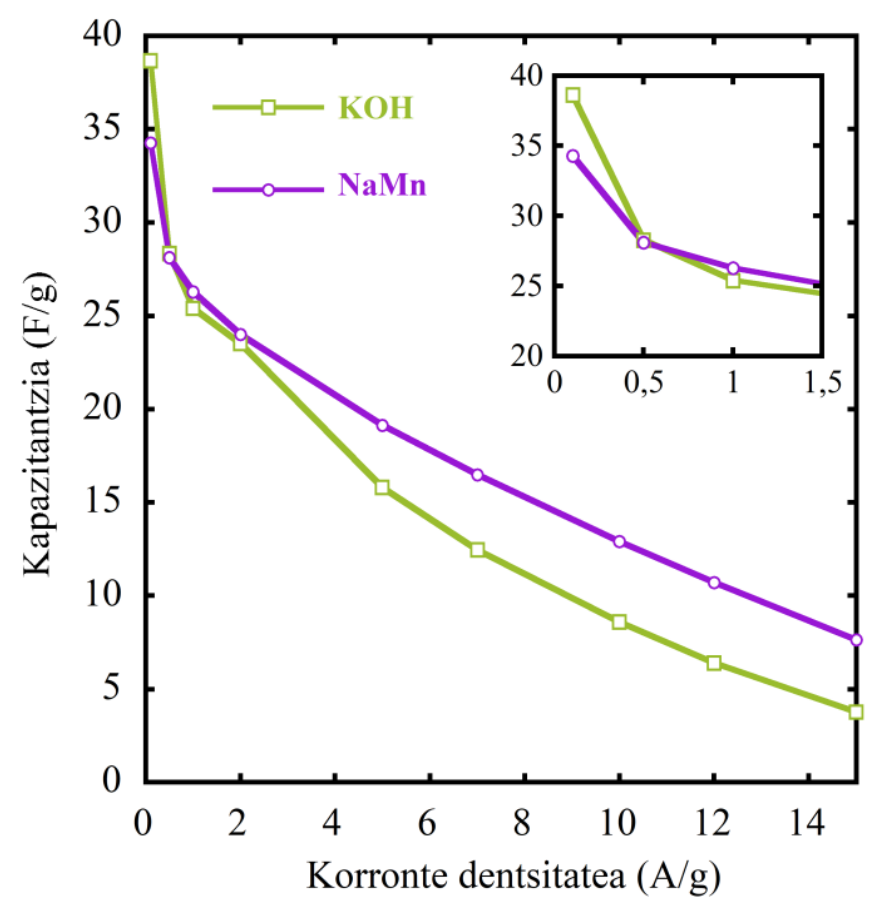

17. Irudia: Karga/deskarga GA-etatik kalkulatutako kapazitantzia espezifikoen konparaketa bi elektrolitoetan.

Bertan ikusten denez, NaMn elektrolitoan lan egin duen gelaxkaren kasuan, lantentsioa handiagoa izateaz gain, kapazitantzia espezifiko balio altuagoak lortu dira ere 
ia aztertutako korronte dentsitate tarte osoan. Beraz, $\delta-\mathrm{MnO}_{2}$ elektrodo positiboa duen superkondetsadore hibrido baterako, aukeratutako elektrolitoa $1 \mathrm{M} \mathrm{KOH}$ eta $0,5 \mathrm{M}$ $\mathrm{Na}_{2} \mathrm{SO}_{4}$ elektrolitoak baino egokiagoa dela esan daiteke. Sistema finalean lortutako kapazitantzia espezifikoaren balioak elektrodoentzat lortutakoak baino nabarmen baxuagoak dira (ikusi 14. Irudia). Izan ere, sarreran esan bezala, superkondentsadore batean elektrodo bakoitza seriean konektatuta dagoen kondentsadore bat bezala uler daiteke, eta beraz, sistema finalaren kapazitantziaren alderantzizkoa bi elektrodoen kapazitantzien alderantzizkoen batura izango da, 9. Ekuazioan agertzen den moduan.

$$
\frac{1}{C_{\text {final }}}=\frac{1}{C_{+}}+\frac{1}{C_{-}}
$$

Bukatzeko ziklabilitatea aztertu da, ezaugarri honek sistema baten kapazitantziaren aldaketa neurtzen du baldintza berdinetan neurtutako hainbat GA karga/deskarga zikloren ostean. Kasu honetan, 1 A/g-ko korronte dentsitatea aplikatuz, 5.000 zikloren ostean sistemek bi elektrolitoetan duten kapazitantzia galera aurkezten da 18. Irudian.

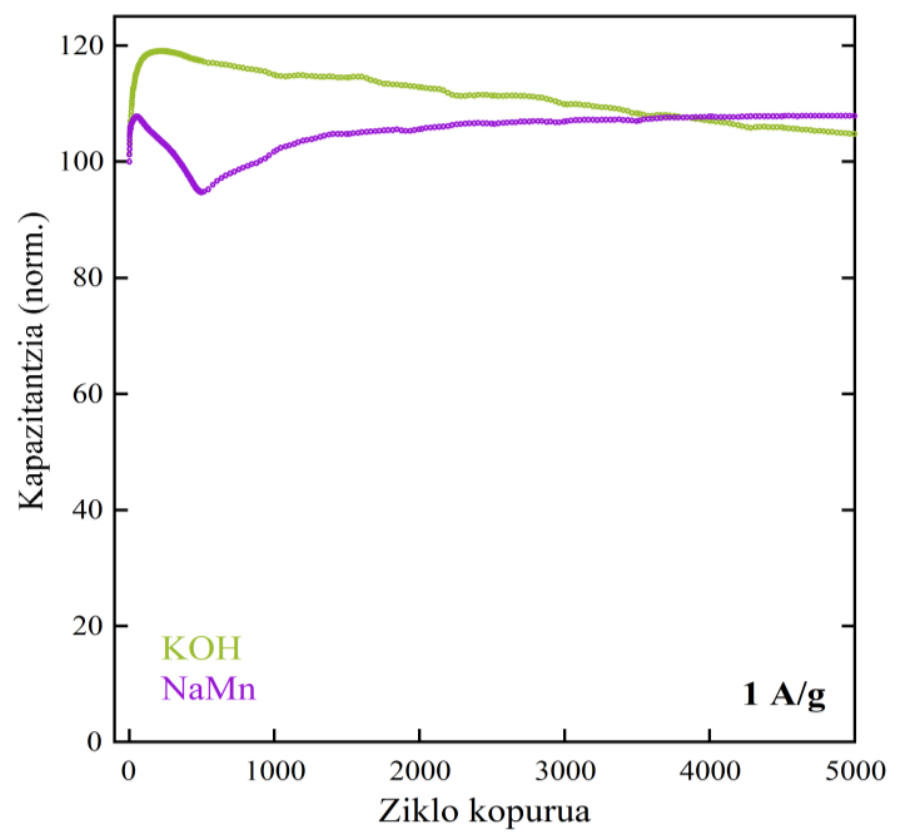

18. Irudia: Ziklabilitatea bi elektrolitoentzako

Hasierako zikloetan, bi sistemen kapazitantzia handitu egin da, pre-egokitze zikloak bezala ezagutzen direnak. KOH-an lan egiten duen sistemak, balio maximotik hasita, \% 13-ko kapazitantzia galera izan du ia linealki. NaMn erabiltzen duen sistemaren 
kasuan aldiz, anomalia bat ikus daiteke ziklabilitatean hasierako 500 zikloetan, ondoren gainditzen den beherakada ikusten baita, baina horren ostean sistemaren kapazitantzia nahiko egonkor mantentzen da. Beraz, 5.000 ziklo eta gero bi sistemek izan duten kapazitantziaren erretentzioa altua izan da, \% 80tik gorakoa, eta ziurrenik elektrolito hauek erabiliz $\mathrm{AC} / \mathrm{MnO}_{2}$ elektrodo bikotearekin aise lortuko lirateke $10.000 \mathrm{karga} /$ deskarga ziklo kapazitantzia galera aipagarririk gabe. ${ }^{40}$

\section{ONDORIOAK}

- Ikerketa honetan, arrakastaz eraiki da laborategi mailako superkondentsadore hibrido bat, $\delta-\mathrm{MnO}_{2}$ erabiliz elektrodo positibo moduan eta ikatz aktibatu komertzial bat elektrodo negatibo gisa.

- $\mathrm{K}_{0,27} \mathrm{MnO}_{2} \cdot 0,27 \mathrm{H}_{2} \mathrm{O}$ formula duen $\delta-\mathrm{MnO}_{2}$ nanoegituratua $\mathrm{KMnO}_{4}$ etilenglikoarekin erreduzituz prestatu da.

- $600{ }^{\circ} \mathrm{C}$-ra arteko tratamendu termikoaren ondorioz hasierako $\mathrm{K}_{0,27} \mathrm{MnO}_{2} \cdot 0,27 \mathrm{H}_{2} \mathrm{O}$ konposatuaren egitura kristalinoa eta partikularen tamaina eta morfologia aldatu egin dira, X-izpien difrakzioa eta mikroskopia elektronikoaren bidez ikusi den bezala.

- Karakterizazio elektrokimikorako $\mathrm{K}_{0,27} \mathrm{MnO}_{2} \cdot 0,27 \mathrm{H}_{2} \mathrm{O}\left(\mathrm{MnO}_{2}\right)$ eta $600{ }^{\circ} \mathrm{C}$-tan prestatutako $\mathrm{K}_{0,26} \mathrm{MnO}_{2}\left(600 \mathrm{MnO}_{2}\right)$ laginak aukeratu dira eta $\mathrm{KOH}$ elektrolitoan kapazitantzia baliorik handienak aurkezten dituzten bitartean $0,5 \mathrm{M} \mathrm{Na}_{2} \mathrm{SO}_{4}+$ 0,2 $\mathrm{mM} \mathrm{MnSO}_{4}$ elektrolitoan potentzial leiho zabalago batean lan egin dezakete.

- $\mathrm{AC} / \mathrm{MnO}_{2}$ sistema final bi eraiki dira, batean $0,1 \mathrm{M} \mathrm{KOH}$ erabiliz elektrolito moduan eta bestean 0,5 $\mathrm{M} \mathrm{Na}_{2} \mathrm{SO}_{4}+0,2 \mathrm{mM} \mathrm{MnSO}_{4}$. Azkeneko kasuan, lortu den lan tentsio zabalagoarengatik ( $2 \mathrm{~V}$ vs. 1,5 V) eta orohar lortutako kapazitantzia balio altuagoengatik, sistema honentzat $0,5 \mathrm{M} \mathrm{Na}_{2} \mathrm{SO}_{4}+0,2 \mathrm{mM} \mathrm{MnSO}_{4}$ elektrolitoa egokiagoa dela ondorioztatu da.

- $5.000 \mathrm{karga/deskarga} \mathrm{zikloren} \mathrm{ostean,} \mathrm{0,5} \mathrm{M} \mathrm{Na}_{2} \mathrm{SO}_{4}+0,2 \mathrm{mM} \mathrm{\textrm {MnSO } _ { 4 }}$ elektrolitoan lan egiten duen sistemak ez du kapazitantzia galerarik aurkeztu.

\section{BIBLIOGRAFIA}

(1) Tarascon, J. M.; Armand, M. Nature 2001, 414 (6861), 359-367.

(2) Brodd, R. J.; Bullock, K. R.; Leising, R. A.; Middaugh, R. L.; Miller, J. R.; Takeuchi, E. J. Electrochem. Soc. 2004, 151 (3), K1-K11. 
(3) Armand, M.; Tarascon, J.-M. Nature 2008, 451 (7179), 652-657.

(4) Armand, M.; Johansson, P. J. Power Sources 2008, 178 (2), 821-825.

(5) Conway, B. E. Electrochemical Supercapacitors : Scientific Fundamentals and Technological Applications; Plenum Press, 1999.

(6) Service, R. F. Science, 2006, 313 (5789), 902-902.

(7) Helmholtz, H. Ann. der Phys. und Chemie 1853, 165 (6), 211-233.

(8) Greentech, la solución de CAF al tranvía sin catenaria https://www.caf.net/es/ecocaf/nuevas-soluciones/tranvia-greentech.php (accessed Jun 4, 2019).

(9) Miller, J. R.; Simon, P. Science, 2008, 321 (5889), 651-652.

(10) Miller, J. R.; Burke, A. F. Interface, 2008, 17 (1), 53-57.

(11) Datasheet: 2.7V 650-3000F Ultracapacitor Cells; Maxwell technologies, 2019.

(12) High power ultracapacitors https://yunasko.com/en/products (accessed Jun 6, 2019).

(13) Nippon chemi-con: DL cap 2018 http://www.chemi-con.co.jp/e/catalog/pdf/dle/dl-all-e1009f-2018.pdf (accessed Jun 6, 2019).

(14) TITAN 2.7V@85 ${ }^{\circ} \mathrm{Cor} 2.85 @ 65^{\circ} \mathrm{C} 60 \mathrm{~mm}$ Axial Cells; IOXUS.

(15) JM energy Corporation: Lithiumion capacitors https://www.jmenergy.co.jp/en/product/cell/ (accessed Jun 6, 2019).

(16) WIMA: SuperCap Double-Layer Capacitors http://wima.cn/EN/supercap_r_2.htm (accessed Jun 6, 2019).

(17) Data Sheet: SkelCap Ultracapacitor; Skeleton technologies, 2017.

(18) Ajuria, J.; Redondo, E.; Goikolea, E. EKAIA, 2017, ale berezia, 97-113.

(19) Goikolea, E.; Mysyk, R. Emerg. Nanotechnologies Recharg. Energy Storage Syst; Elsevier, 2017.

(20) Conway, B. E. Electrochemical Supercapacitors : Scientific Fundamentals and Technological Applications; Springer US, 1999. 
(21) Zhang, X.; Zhang, H.; Li, C.; Wang, K.; Sun, X.; Ma, Y. RSC Adv. 2014, 4 (86), $45862-45884$.

(22) McDonough, J. K.; Frolov, A. I.; Presser, V.; Niu, J.; Miller, C. H.; Ubieto, T.; Fedorov, M. V. Carbon N. Y. 2012, 50 (9), 3298-3309.

(23) Shi, H. Electrochim. Acta 1996, 41 (10), 1633-1639.

(24) Berenguer, R.; Bol. Grupo Español Carbón, 2015, 37, 9-13.

(25) González, A.; Goikolea, E.; Barrena, J. A.; Mysyk, R. Renew. Sustain. Energy Rev. 2016, 58, 1189-1206.

(26) Béguin, F.; Frąckowiak, E. Supercapacitors: Materials, Systems, and Applications; Wiley-VCH, 2013.

(27) Thomas, J. Energy Environ. Sci. 2015, 8 (3), 702-730.

(28) Yang, C.-M.; Kim, Y.-J.; Endo, M.; Kanoh, H.; Yudasaka, M.; Iijima, S.; Kaneko, K. J. Am. Chem. Soc. 2007, 129 (1), 20-21.

(29) Béguin, F.; Presser, V.; Balducci, A.; Frackowiak, E. Adv. Mater. 2014, 26 (14), 2219-2251.

(30) Ohno, H. Electrochemical Aspects of Ionic Liquids; Wiley, 2011.

(31) Lin, R.; Taberna, P.-L.; Fantini, S.; Presser, V.; Pérez, C. R.; Malbosc, F.; Rupesinghe, N. L.; Teo, K. B. K.; Gogotsi, Y.; Simon, P. J. Phys. Chem. Lett. 2011, 2 (19), 2396-2401.

(32) Zhao, D.-D.; Bao, S.-J.; Zhou, W.-J.; Li, H.-L. Electrochem. commun. 2007, 9 (5), 869-874.

(33) Wang, G.; Zhang, L.; Zhang, J. Chem. Soc. Rev. 2012, 41 (2), 797-828.

(34) Toupin, M.; Brousse, T.; Bélanger, D. Chem. Mater. 2002, 14 (9), 3946-3952.

(35) Chang, J.-K.; Lee, M.-T.; Tsai, W.-T. J. Power Sources 2007, 166 (2), 590594.

(36) Toupin, M.; Brousse, T.; Bélanger, D. Chem. Mater. 2002, 14 (9), 3946-3952.

(37) Pang, S.-C.; Anderson, M. A.; Chapman, T. W. J. Electrochem. Soc. 2000, 147 (2), 444-450. 
(38) Devaraj, S.; Munichandraiah, N. Electrochem. Solid-State Lett. 2005, 8 (7), A373-A377.

(39) Chen, Y.-S.; Hu, C.-C. Electrochem. Solid-State Lett. 2003, 6 (10), A210-A213.

(40) Sharma, R. K.; Oh, H.-S.; Shul, Y.-G.; Kim, H. J. Power Sources 2007, 173 (2), $1024-1028$.

(41) Brousse, T.; Long, J. W.; Bélanguer, D. Interface, 2008, 17 (1), 49-52.

(42) Ragupathy, P.; Park, D. H.; Campet, G.; Vasan, H. N.; Hwang, S.-J.; Choy, J.H.; Munichandraiah, N. J. Phys. Chem. C 2009, 113 (15), 6303-6309.

(43) Sing K.S.W.; Everett D.H.; Haul, R. A. W.; Moscou L.; Piertti R.A.; J.Rouquerol; T.Siemienieswska. Pure Appl. Chem. 1985, 57 (4), 603-619.

(44) Ghodbane, O.; Pascal, J. L.; Fraisse, B.; Favier, F. ACS Appl. Mater. Interfaces 2010, 2 (12), 3493-3505.

(45) Yang, X.; Makita, Y.; Liu, Z.; Sakane, K.; Ooi, K.; Chem. Mater. 2004, 16 (26), $5581-5588$

(46) Valente, J. S.; Frías, D.; Navarro, P.; Montes, M.; Delgado, J. J.; Fregoso-Israel, E.; Torres-García, E. Appl. Surf. Sci. 2008, 254 (10), 3006-3013.

(47) Qu, Q.; Li, L.; Tian, S.; Guo, W.; Wu, Y.; Holze, R. J. Power Sources 2010, 195 (9), 2789-2794.

(48) Liu, C.; Chen, Y.; Dong, Z.; Wu, X.; Situ, Y.; Huang, H. Electrochim. Acta 2019, 298, 678-684. 